\title{
Micronutrient Metabolism in Hemodialysis Patients
}

\author{
Chih-Hung Guo ${ }^{1}$, Chia-Liang Wang ${ }^{2}$ and Pei-Chung Chen ${ }^{1}$ \\ ${ }^{1}$ Institute of Biomedical Nutrition, Hung-Kuang University, \\ 2Department of Nephrology, Kuang-Tien General Hospital,
}

Taiwan

\section{Introduction}

Patients with end stage renal diseases (ESRD) that require long-term dialysis treatment still have high morbidity and mortality rates. Risk factors that are associated with outcomes and survival rates include long dialysis duration, medical complications, oxidative stress, infection, inflammation, and impaired immune responsiveness. Some studies have been investigated associations of disturbances of certain micronutrients in patients undergoing dialysis. However, the homeostasis of these micronutrients plays a critical role in the maintenance of antioxidant status and immune function, and the amelioration of infection. This chapter will focus on the associations between micronutrients (trace elements and vitamins) status and these risk factors and their potential therapeutic uses in hemodialysis patients. In addition, we review other special nutrients (substrates) that are essential for patient management.

\section{Main risk factors: Inflammation $\&$ oxidative stress}

ESRD patients who undergo long-term hemodialysis can develop cardiovascular diseases, anemia, protein-calorie malnutrition, infections and altered immune function, renal osteodystrophy, and skin disorders, which are common complications (Himmelfarb, 2005). These patients already have a high incidence of cardiovascular disease, and half of the deaths among these patients can be attributed to induced cardiovascular disease (Bevc et al., 2006). In view of the accelerated atherosclerosis, some traditional risk factors as well as nontraditional factors that occur in dialysis patients have been reported.

In contrast to cardiovascular disease, other complications can be partly explained by these known risk factors. Increasing evidence shows that patients on dialysis have oxidative stress and inflammation. Relative to healthy controls, these patients have significantly higher plasma concentrations of lipid peroxidation products expressed as thiobarbituric acidreactive substances (TBARS), malondialdehyde (MDA)(Guo et al., 2010; Kirmizis et al., 2010), advanced oxidation protein products (AOPP)(Taki et al., 2006; Chen et al., 2011), and oxidative DNA products (8-hydroxydeoxyguanosine, 8-OHdG)(Morishita et al., 2011). Chronic inflammation in hemodialysis patients is characterized by elevated concentrations of inflammatory markers and cytokines, such as C-reactive protein (CRP), interleukin-1 $\beta$ 


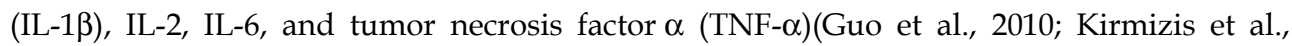
2010). Cytokines are also important mediators involved in systemic inflammatory diseases. Oxidative stress is closely associated with inflammatory status, and the maintenance of the redox balance is known to modulate immune system homeostasis in hemodialysis patients. Chronic inflammation can induce an increased production of free radicals that cannot be counterbalanced due to defective antioxidant capability; an altered redox state is responsible for the accelerated dialysis syndromes. Oxidative stress occurs at sites of active inflammation and as a part of the reaction to invasive microorganisms (Nihi et al., 2010). Increased oxidative stress is also markedly related to the retention of oxidized solutes, the dialyzer membrane, bacterial contaminants in the dialysate, mitochondrial dysfunction, and decreased levels of antioxidant enzymes, including superoxide dismutase (SOD), catalase and glutathione peroxidase (GPx)(Dursun et al., 2002; Ward and McLeish, 2003; Himmelfarb, 2008).

Oxidative stress has been implicated in other long-term complications, including anemia, amyloidosis, malnutrition, and infection (Morena et al., 2005). Infection may aggravate micronutrient deficiencies by reducing nutrient intake, increasing losses, and interfering with utilization by altering metabolic pathways (Maggini et al., 2007). Poor nutritional status arises due to increased oxidative stress, and the latter may be related to alterations in micronutrients' homeostasis in hemodialysis patients. Overall, lowered micronutrients' status can promote oxidative stress and inflammatory responses may lead to suppressed immunity, which predisposes to infections and aggravates malnutrition.

\section{Trace elements}

\subsection{Zinc}

Zinc (Zn), an essential trace element, is an integral part of many enzyme functions and is a cofactor in those signaling pathways involving Zn-requiring proteins (Ngom et al., 2011). Zn is also an antioxidant and has anti-inflammatory properties. For example, $\mathrm{Zn}$ plays a critical structural role for antioxidant enzyme SOD and can stabilize biological membranes to decrease their susceptibility to oxidative damage that can impair cell functions (O'Dell, 2000). $\mathrm{Zn}$ is also a part of $\mathrm{Zn}$-fingers and increases metallothionein biosynthesis, which can act as an antioxidant.

Several studies have demonstrated that $\mathrm{Zn}$ homeostasis has a critical impact on the health of hemodialysis patients. These patients have significantly lower concentrations of $\mathrm{Zn}$ in the blood and leukocytes and have increased oxidative stress (Roozbeh et al., 2009; DashtiKhavidaki et al., 2010). The possible causes of decreased Zn concentrations need to be clarified, although $\mathrm{Zn}$ removal during hemodialysis, decreased gastrointestinal absorption of $\mathrm{Zn}$, inadequate $\mathrm{Zn}$ intake, and reduced $\mathrm{Zn}$-binding proteins in these patients have been reported. Increased expressions of intracellular metallothioneins following oxidative damage can sequester plasma $\mathrm{Zn}$, and up-regulation of $\mathrm{Zn}$-importing proteins by proinflammatory cytokines can reduce the plasma concentrations of Zn (Liuzzi et al., 2005; Haase and Rink, 2009; Guo et al., 2011). CRP is considered to be a sensitive marker of the induction of inflammatory activity; an association between decreased plasma $\mathrm{Zn}$ concentrations with higher CRP levels in hemodialysis patients has been noted (Guo et al., 2010). Medications used by hemodialysis patients, such as calcium carbonate, calcitriol (Dashti-Khavidaki, 2010), and aluminum phosphate-binders (our unpublished results), may interfere with blood $\mathrm{Zn}$ concentrations. 
Efficient immune function depends on the status of some micronutrients and an inadequate status may lead to depressed immune responses. $\mathrm{Zn}$ is an immune regulator with multiple functional activities for immune effector cells, such as natural killer cell activity, and chemotaxis of neutrophils and monocytes (Kreft et al., 2000). Disturbances in Zn homeostasis can lead to a shift in the Th1/Th2 balance towards a Th2 response. In hemodialysis patients with Zn deficiency, the percentages of circulating CD3 and CD4 T lymphocytes are significantly lower than in controls; plasma $\mathrm{Zn}$ concentrations are correlated with \%CD3 and \%CD4 T cells, and CD4/CD8 ratios (Guo et al., 2010).

Zn deficiency has also been found to be associated with some uremic symptoms, such as anorexia, impaired taste sensation, and sexual dysfunction. On the other hand, depression is a common psychological problem encountered among ESRD patients. Chronic inflammation is known to play an important role in the pathophysiology of depression, and the concentrations of pro-inflammatory cytokines are increased in these patients (Bilgic et al., 2007; Maes, 2008). An association between Zn deficiency with depression in hemodialysis patients has been noted (Roozbeh et al., 2011). Recent investigations suggest a positive association between blood $\mathrm{Zn}$ concentrations and albumin, hematocrit and prealbumin, which suggests that better nutritional status is a reason for higher $\mathrm{Zn}$ status in dialysis patients (Grzegorzewska and Mariak, 2001; Navarro-Alarcon et al., 2006). In addition, Zn promotes insulin-like growth factor-1 (IGF-1), which plays a role in the regulation of hematopoiesis and osteoclastogenesis (Nishiyama et al., 1999; Yamaguchi et al., 2010). Thus, Zn status also seems to be related to hemodialysis bone disease and anemia. $\mathrm{Zn}$ supplementation can increase blood $\mathrm{Zn}$ concentrations, leading to an increased protein catabolic rate (Jern et al., 2000), decreased osmotic fragility and lipid peroxidation (Candan et al., 2002), and reduced CRP levels (Rashidi et al., 2009) in hemodialysis patients. Zn supplementation ( $50 \mathrm{mg}$ of elemental $\mathrm{Zn}$ from $\mathrm{Zn}$ sulfate for 90 days) improved food intake and serum cholesterol status in hemodialysis patients (Chevalier et al., 2002). Furthermore, our unpublished results showed that hemodialysis patients who received $10 \mathrm{mg}$ of elemental Zn (78 mg of Zn gluconate) for 2 months had increased plasma Zn concentrations, reduced oxidative stress, and improved immune function. Sexual dysfunction in chronic renal failure patients undergoing hemodialysis is also common. $\mathrm{Zn}$ administration (100 $\mathrm{mg}$ / day for 6 weeks) can significantly increase serum concentrations of $\mathrm{Zn}$ and testosterone (Jalali et al., 2010). Most maintenance hemodialysis patients suffer from anemia, and Znbased polaprezinc ( $34 \mathrm{mg} \mathrm{Zn/day} \mathrm{for} 21$ days) has been confirmed to provide an improved response to erythropoietin and increase hemoglobin levels (Fukushima et al., 2009).

In summary, low Zn status is likely to be more common and Zn supplementation would appear to be beneficial for Zn-deficient patients undergoing chronic hemodialysis. Zn status may alter the risk of complications of hemodialysis, which results from improved nutrition, antioxidant, and anti- inflammatory properties.

\subsection{Copper}

Copper $(\mathrm{Cu})$ is an essential trace element that is required for a number of enzymes. $\mathrm{Cu}$ has vital roles in hemoglobin synthesis and immune function and is also a cofactor for SOD, cytochrome c oxidase, and ceruloplasmin (Maggini et al., 2007). Regarding the antioxidant enzyme SOD, Cu provides its catalytic activity. However, excess blood $\mathrm{Cu}$, particularly the free fraction, may lead to tissue injury apparently due to its pro-oxidant effects and the depletion of anti-oxidant reserves. 
Although the actual cause for changes in $\mathrm{Cu}$ concentrations and distribution remains to be elucidated, long-term dialysis patients have elevated concentrations of plasma $\mathrm{Cu}$ and increased oxidative stress compared to healthy controls (Navarro-Alarcon et al., 2006; Tonelli et al., 2009; Guo et al., 2010). The prescription of different phosphate binders did not have any observable effects on serum $\mathrm{Cu}$ status (Veighey et al., 2011). However, Zn deficiency may increase the absorption of intestinal $\mathrm{Cu}$ and $\mathrm{Cu}$ can significantly inhibit the influx of $\mathrm{Zn}$ across the intestinal brush border membrane. The release of $\mathrm{Cu}$ during inflammatory tissue damage also can explain the enhancement of blood $\mathrm{Cu}$ concentrations (Guo et al., 2009). Moreover, mitochondrial dysregulation affects $\mathrm{Cu}$ chaperone expressions (Granata et al., 2009), which may result in impaired $\mathrm{Cu}$ homeostasis and increased oxidative stress in hemodialysis patients.

An increased $\mathrm{Cu}$ concentration in erythrocytes or blood is accompanied by an increase in oxidative stress and an increased TBARS concentration in hemodialysis patients (Bober et al., 2007; Guo et al., 2010). In addition, chronic inflammation, as indicated by an increased concentration of serum ceruloplasmin, is related to elevated concentrations of CRP and $\mathrm{Cu}$ (Panichi et al., 2004). Previous studies have shown that higher concentrations of CRP, Cu, $\mathrm{Cu} / \mathrm{Zn}$ ratio, and ceruloplasmin are related to inflammatory status (Bo et al., 2008; GhayourMobarhan et al., 2008). Elevations in plasma $\mathrm{Cu}$ can increase protein kinase $\mathrm{C}$ activation due to oxidative stress and these are associated with inflammation and the progression of renal diseases (Davis et al., 2001).

Recently, $\beta$-2-microglobulin deposits in the form of amyloid fibrils were found in the musculoskeletal systems of dialysis patients as a result of kidney failure (Srikanth et al., 2009). $\beta$-2-microglobulin accumulation with resultant tumor formation is also a known, albeit rare complication of long-term hemodialysis (Mendoza et al., 2010). $\beta$-2-microglobulin has been reported to be markedly correlated with oxidative stress and inflammatory biomarkers in hemodialysis patients (Filiopoulos et al., 2009). However, $\mathrm{Cu}$ binding to $\beta-2-$ microglobulin may precede amyloid formation (Srikanth et al., 2009).

Elevated serum and leukocyte $\mathrm{Cu}$ concentrations were associated with cardiovascular disease; $\mathrm{Cu}$ may directly affect atherogenesis and is a marker of inflammation associated with atherosclerosis (Kinsman et al., 1990; Ford, 2000). Higher blood Cu status may subsequently promote the development of breast cancer, and the adjusted odds ratios for breast cancer were 1.8, 1.0, 1.6, and 3.2, respectively, in the 4 quartiles of $\mathrm{Cu}$ distribution (Overvad et al., 1993). Whether or not $\mathrm{Cu}$ homeostasis has an impact on the development of atherosclerosis and some types of cancer in long-term dialysis patients remains to be established.

Variations in the distributions of both $\mathrm{Cu}$ and $\mathrm{Zn}$ can actually indicate oxidative stress, inflammation status, and immune dysfunction in dialysis patients. There is no question that disturbance in blood $\mathrm{Cu}$ remains a major problem and that $\mathrm{Zn}$ supplementation may benefit hemodialysis patients.

\subsection{Selenium}

Trace element selenium (Se) is required for the functions of a number of Se-dependent enzymes. Se bound to the active sites of antioxidant enzyme GPx plays an important role in protecting cell membranes and sub-cellular components from oxidative damage. Thus, Se is a potent antioxidant that acts as an anti-inflammatory agent and is required for immune system function (Rayman, 2000). Se can simulate Th1 immune responses against viral 
infections and is involved in thyroid hormone synthesis (Kocabaş et al., 2006). Adequate Se status is necessary for maintenance of cell-mediated immunity and humoral immunity. In addition, the association of plasma Se concentrations with subsequent risk of cancer has been described. We are currently conducting clinical trials in our laboratory; the antiangiogenesis effects of supranutritional levels of Se are consistently observed in three types of cancer.

The kidney accumulates the highest amounts of Se and is the major source of plasma GPx (Adamowicz et al., 2002). The plasma concentrations of Se and GPx activities are significantly lower in dialysis patients than in healthy controls (Zagrodzki et al., 2007; Tonelli et al., 2009; Pakfetrat et al., 2010; Fujishima et al., 2011a). Reduced intake of Se lowers the blood Se status of dialysis patients (Andrew et al., 2008). Increased inflammation may decrease the absorption of Se and result in low Se status (Walston et al., 2006). Blood Se status is also significantly associated with albumin concentration and the dialysis process (Fujishima et al., 2011a); lower Se status may be related to malnutrition in these patients.

Further, statins (3-hydroxy-3-methyl-glutaryl-CoA reductase inhibitors) also have antioxidant and anti-inflammatory properties, which can further reduce the numbers of inflammatory cells and CRP concentrations (Ferms, 2003). In hemodialysis patients who used statins, blood Se concentrations were significantly higher compared with untreated patients (Taccone-Gallucci et al., 2010). Thus, this raises the possibility that low Se concentrations may be attributed to diminished Se retention due to increased oxidative stress.

Patients undergoing hemodialysis have low Se status that may increase their risk of anemia and certain cancers (Viron, 2002). On the other hand, a population-based prospective cohort study has conducted among hemodialysis patients showed that low blood Se status may contribute to immune system dysfunction and an increased risk of death, especially death related to infectious disease (Fujishima et al., 2011b). Se status was significantly associated with decreased IL-6 concentrations and altered erythrocyte membrane fluidity in these patients (McGrath et al., 1995; Walston et al., 2006), and Se supplementation stimulated erythrocyte GPx enzyme activity and reduced NF-kB activation in HIV-infected patients (Kupka et al., 2004). A previous investigation also showed an association between CRP and low Se concentrations in dialysis patients (Guo et al., 2010). This suggests a relationship between the reduced concentrations of plasma Se and the increased inflammatory responses of hemodialysis patients.

Se supplements such as sodium selenate, sodium selenite, L-selenomethionine, and Seenriched yeast, are available to counter potential deficiencies. However, organic forms of Se are more bioavailable and are found to be less toxic than inorganic Se. Se-containing yeast (150 $\mu \mathrm{g}$ Se/day) supplementation, was effective for increasing blood Se concentrations in healthy adults, whereas the same amount of inorganic forms failed to raise blood Se concentrations (Schrauzer, 1979). For hemodialysis patients who received oral supplementations of sodium selenite $(230 \mu \mathrm{g}$ Se/day) for 3 months, followed by $200 \mu \mathrm{g} /$ day for the next 3 months, their plasma Se concentrations increased until reaching a plateau similar to control levels (Saint-Georges et al., 1989). Hemodialysis patients who received supplements of $200 \mu \mathrm{g}$ of Se (as Se-rich yeast) per day for 3 months had significantly higher plasma Se concentrations and decreased leukocyte DNA damage (Zachara et al., 2010). Serich yeast supplementation (200 $\mu \mathrm{g}$ Se/day for 3 months) for hemodialysis patients 
significantly increased blood Se concentrations, but had no effect on plasma levels of GPx protein (Zachara et al., 2009). Rapidly increased plasma GPx activity was found following kidney transplantation (Whitin et al., 1998). Thus, the damaged kidney is unable to synthesize GPx, even after induction with Se. In contrast, erythrocyte GPx in the kidney is primarily synthesized in the proximal tubules (Whitin et al., 1998). Treatment with yeast-Se (900 $\mu \mathrm{g}$ of Se/week) caused an increase in Se concentrations and erythrocyte GPx activity (Zachara et al., 2001).

On the other hand, increased plasma Se is positively associated with indices of erythropoiesis and nutritional status (Zagrodzki et al., 2007). Significantly increased Se concentrations were seen after 4-months of recombinant human erythropoietin (rHuEpo) treatment (Celiker et al., 2001). In contrast, Se deficiency, particularly when combined with viral infection, can cause cardiovascular disease (DiSilvestro, 2005). Patients on hemodialysis have a higher prevalence of hepatitis $C$ virus infection, may be attributed to the decreased plasma Se concentrations and GPx activities (our unpublished observations). Reduced serum Se and platelet GPx activity in hemodialysis patients are related to cardiovascular complications (Girelli et al., 1993). Se supplementation may help to prevent cardiovascular disease due to its antioxidant capacity, improvement in blood lipids, and the inhibition of platelet aggregation (Nève, 1996; Panicker et al., 2010; Rayman et al., 2011).

Se deficiency may alter immune function, increase oxidative stress, and increase the generation of inflammatory cytokines, which is complicating the clinical features in hemodialysis patients. The clinical manifestations of Se deficiency have a late onset; a deficiency may be present for a long time before these manifestations appear. Thus, there is a need for routine assessments of Se status and the efficacy of Se supplementation for hemodialysis patients.

\section{Vitamins}

\subsection{Vitamin C}

Vitamin C, also known as ascorbic acid, is a potent water-soluble antioxidant and coenzyme in hydroxylation reactions and has anti-mutagenic properties. Vitamin $C$ plays an important role in the synthesis of neurotransmitters that are critical for brain function and that are known to affect mood (see the web from the Linus Pauling Institute). Vitamin C is also required for the synthesis of collagen and carnitine.

Hemodialysis patients are particularly prone to vitamin $C$ deficiency because of dietary restrictions, limited absorption, and poor nutritional status (Böhm et al., 1997; Richter et al., 2008). The dialysis process may decrease the blood concentrations of vitamin $C$ (Deicher et al., 2005). Significantly decreased plasma vitamin C and increased oxidative stress were seen during hemodialysis, which could be exacerbated by intravenous iron treatment (Shi et al., 2005). Also, increased weekly hours of dialysis increase the loss of vitamin C (Coveney et al., 2010). Vitamin C homeostasis may have a significant impact on these patient outcomes.

Daily intake of $60-100 \mathrm{mg}$ of vitamin $\mathrm{C}$ is sufficient to maintain health in the general population, but may not be adequate for dialysis patients (Richter et al., 2008). Although, short-term oral vitamin C supplementation ( $250 \mathrm{mg}$ at 3 times/week for 2 months) did not alter oxidative stress and inflammatory markers in hemodialysis patients (Fumeron et al., 
2005). Every other day supplementation with $250 \mathrm{mg}$ of vitamin $C$ for 3 months increased blood vitamin $\mathrm{C}$ concentrations, decreased MDA, and improved LDL and total cholesterol concentrations (Abdollahzad et al., 2009). Several polypeptides associated with oxidative stress and inflammatory markers were also normalized after oral vitamin C supplementation (250 $\mathrm{mg}$ at 3 times/week)(Weissinger et al., 2006). For hemodialysis patients who were given 1,000 mg of vitamin C for 3 months (Washio et al., 2008) or for 1 year (Ramos et al., 2005), decreased LDL oxidation, increased plasma vitamin C and plasma SOD activity, but not SOD mRNA expression in leukocytes were noted. After intravenous administration of vitamin C, ESRD patients also showed increased paraoxonase activity and vitamin E, decreased AGE, isoprostances, 8-OHdG and lipid peroxidation concentrations, and reductions in pro-inflammatory mediators (Chien et al., 2004; Tarng et al., 2004; Shi et al., 2005; Chan et al., 2006; Ferretti et al., 2008).

A high dietary intake and high circulating concentrations of vitamin $\mathrm{C}$ may protect against ischemic heart disease, possibly due to its antioxidant properties and anti-inflammatory effects (Wannamethee et al., 2006). Inverse relationships between vitamin $C$ status with CRP, IL-6, fibrinogen, coagulation factors VII, VIII, and IX, and thrombin-antithrombin complexes have also been noted (Deicher et al., 2005). Therefore, low total vitamin C plasma concentrations may be an independent predictor of adverse cardiovascular outcomes for hemodialysis patients; vitamin $C$ supplementation has been suggested to reduce cardiovascular disease risk.

Hemodialysis patients with functional iron deficiencies often develop resistance to rHuEpo. For these patients, anemia prevention relies primarily on supplemental EPO and intravenous iron. Improved vitamin $C$ status and decreased inflammation could lead to better utilization of iron and EPO (Handelman, 2007). Plasma concentrations of vitamin C are positively associated with hemoglobin concentrations, and vitamin $\mathrm{C}$ status may help patients to utilize iron for erythropoiesis during anemia management (Attallah et al., 2006; Deved et al., 2009; Finkelstein et al., 2011). Anemic hemodialysis patients who received oral daily vitamin $\mathrm{C}$ at a dose of $500 \mathrm{mg}$ /day had decreased ferritin concentrations and EPO dose requirements, while hemoglobin and hematocrit concentrations were increased (Sirover et al., 2008).

On the other hand, long-term dialysis patients have a decreased quality of life compared to healthy controls (Mydlik and Derzsiová, 2008). Increased malnutrition-inflammation scores may be significantly associated with depression, sleep disorders, and poor quality of life (Bilgic et al., 2007). Lower quality of life scores were positively related to decreased blood status of the antioxidants Zn, Se, and vitamin C (Raimundo et al., 2006). When healthrelated quality of life was assessed using Short Form 36 (SF-36) scale scores, associations between plasma vitamin $\mathrm{C}$ status, MDA and life quality were also found in EPO-treated hemodialysis patients (Guo, C-H., unpublished results). Hemodialysis patients who were treated with EPO and were supplemented over 3 months with vitamin B6 (20 mg/day), folic acid (10 mg/week), and vitamin C (60 mg/day), showed increased quality of life scores (Mydlik and Derzsiová, 2008).

Oral or parenteral iron administration is a common practice for hemodialysis patients. However, a major concern is that an oversaturation of transferrin and subsequent propagation of redox-active iron can occur with the recommended dose of iron (Ardalan et al., 2007). Redox-active iron is a potent pro-oxidant that triggers free-radical chain reactions. Vitamin C may also act as a pro-oxidant via the reduction of ferric ion. Hemodialysis 
patients who received $100 \mathrm{mg}$ of iron sucrose and vitamin C intravenously had an increase in oxidative stress comparable to patients given iron alone (Eiselt et al., 2006); however, this finding was not confirmed by Shi et al (2005). This suggests that combination treatment of high doses of iron and vitamin $\mathrm{C}$ by intravenously route, should be avoided in anemic hemodialysis patients.

In addition, hyperoxaluria due to vitamin C supplementation ( $500 \mathrm{mg} /$ day for 3 months) for chronic dialysis patients was found (Sirover et al., 2008). A concern has been raised that high plasma oxalate concentrations may lead to deposition in soft tissues. Nevertheless, one study found that there was no evidence that vitamin $C$ supplementation increased the risk of kidney stone formation (Curhan, 1999). An earlier study involving 45,251 peoples with no history of kidney stones and who were followed for 6 years found that those who had consumed $1500 \mathrm{mg}$ or more of daily vitamin C had a reduced risk of kidney stones compared to those who consumed less than $250 \mathrm{mg}$ daily (Curhan, 1996). Vitamin C supplementation may address the potential protective effects on the clinical outcomes; however, hemodialysis patients should also be advised not to ingest excess amounts of vitamin $\mathrm{C}$ supplements.

\subsection{Vitamin E}

Vitamin E is a family of tocopherols (alpha-, beta-, gamma-, and delta-) and tocotrienols (alpha-, beta-, gamma-, and delta-). Vitamin $\mathrm{E}$ is a fat-soluble vitamin with a variety of cellular membrane stabilizing- antioxidant and non-antioxidant activities. Some studies have been suggested that vitamin E can be used as an erythropoietic agent for decreasing premature erythrocyte hemolysis by reducing membrane fragility and the oxidation of cell membrane polyunsaturated fatty acids (Jilani and Iqbal, 2011). Vitamin E also has anti-tumor effects and is anti-atherogeneic due to its antioxidant effects. Vitamin E supplementation has shown antiproliferative, pro-apoptotic, and cyclooxygenase-2- inhibiting effects (Wada, 2011). Vitamin E is a nutrient known for promoting optimal immune function. When given orally, vitamin $\mathrm{E}$ has been shown to significantly enhance both cell mediated and humoral immune functions in humans and animals (Pekmezci, 2011). Vitamin E supplementation increases IL-2 production by T cells, enhances Th1 responses, and decreases the production of IL-4, a stimulator of Th2 responses (Maggine et al., 2007).

The plasma concentrations of vitamin $\mathrm{E}$ in chronic renal insufficiency patients may be decreased or normal (Yukawa et al., 1999; Hodkova et al., 2006; Zwolinska et al., 2009; Guo et al., 2011). In addition, abnormal distributions of vitamin $\mathrm{E}$ in different lipoproteins have been reported (Yukawa et al., 1999). After hemodialysis, the concentrations of high density lipoprotein (HDL)-cholesterol, vitamin E, and the total antioxidant capacity are significantly decreased (Montazerifar et al., 2010). In comparison to control subjects, LDL from dialysis patients contained less amounts of vitamin E and the MDA of LDL was significantly increased (Yukawa et al., 1999). Two studies evaluated vitamin E (600 IU) or multiple vitamins (800 IU of vitamin E, $250 \mathrm{mg}$ of vitamin C, $100 \mathrm{mg}$ of vitamin B6, $250 \mu \mathrm{g}$ of vitamin B12 and $10 \mathrm{mg}$ of folate) for possible effects on oxidative stress and inflammation in chronic hemodialysis patients; however, neither of these studies found any of the expected effects (Hodkova et al., 2006; Kamgar et al., 2009). This may have been due to not investigating patients with increased oxidative stress. However, oral administration of vitamin E (400 IU) and sodium selenide $(600 \mu \mathrm{g})$, taken $6 \mathrm{~h}$ before a dialysis session, markedly reduced 
oxidative stress in hemodialysis patients who were receiving iron infusions (Ardalan et al., 2007).

Alpha-tocopherol (800 IU) taken daily for 12 weeks decreased the susceptibility of LDL to oxidation in dialysis patients (Islam et al., 2000). The SPACE study, which examined hemodialysis patients, reported that $800 \mathrm{IU} /$ day of alpha-tocopherol significantly reduced cardiovascular disease endpoints and myocardial infarction (Boaz et al., 2000). Moreover, oral vitamin E supplementation (> $800 \mathrm{IU}$ ) for 20 weeks significantly decreased the concentrations of plasma F2-isoprostanes in hemodialysis patients with increased oxidative stress (Reed et al., 2009). This suggests that adequate supplementation of vitamin E is needed in hemodialysis patients.

By comparison, a dialyzer membrane modified with vitamin E provided more effective antioxidant defense than oral administration of 600 IU of vitamin E for hemodialysis patients (Mydlík et al., 2001). Vitamin E bound to a dialyzer membrane resulted in lowered plasma MDA and oxidized LDL and MDA-LDL, and significantly increased the plasma vitamin E concentrations (Mune et al., 1999; Morimoto et al., 2005; Mydlik and Derzsiová, 2008). Although treatment with a vitamin E-coated dialyzer significantly reduced the percentage increase in an aortic calcification index after 24 months (Mune et al., 1999), whether a vitamin E-coated dialyzer can prevent cardiovascular disease and other dialysisrelated complications needs further exploration.

\subsection{Folic acid}

Folic acid (folate) is a water-soluble vitamin essential for a number of critical metabolic pathways. The pteridine moiety of folate is the prosthetic group of many enzymes that are involved in the transfer of one-carbon unit in amino acid and nucleotide metabolism, mitochondrial protein synthesis, conversion of homocysteine to methionine, methylation of transfer RNA, and de novo purine nucleotide synthesis.

Folate is involved in the remethylation of homocysteine to methionine; therefore, a low folate status results in an accumulation of homocysteine. Hyperhomocysteinemia is recognized as an independent risk factor for atherosclerotic cardiovascular diseases, neurodegenerative conditions, osteoporosis, and cancers. Homocysteine and its by-products (homocysteine thiolactone) have been shown to damage the endothelial cells and exacerbate the cardiovascular injury (Jakubowski, 2008). Further, homocysteine increased the affinity of N-methyl-D-asparate (NMDA) glutamate subreceptors, which indirectly caused the calcium influx (Obeid and Herrmann, 206). Increasing evidence shows that homocysteine thiolactone induce protein unfolding and aggregation, and can lead to the formation of amyloid fibrils (Paoli et al., 2010). DNA methylation plays an essential role in maintaining cellular function, and reduced DNA methyltransfrerase may contribute to the development of certain cancers (Davis and Uthus, 2004). In addition, homocysteine increased bone resorption and stimulated p38 mitogen-activated protein kinase (MAPK) activity, and inhibited collagen cross-linking in bone may contribute to osteoporosis (Jamal et al., 2005; Koh et al., 2006).

Some studies have noted that a significantly lower plasma concentration of folate and a higher homocysteine concentration in these patients (Tamura et al., 1996; Stanford et al., 2000). The increased incidence of atherosclerotic vascular disease is correlated with the status of blood homocysteine in ESRD patients undergoing dialysis (Bachman et al., 1995; Heinz et al., 2009). Moreover, blood homocysteine concentrations were found to be 
significantly above the cutoff of $13.5 \mu \mathrm{mol} / \mathrm{L}$ in chronic dialysis patients, with or without vascular diseases (Leblanc et al., 2000; Tremblay et al., 2000). An increase in homocysteine concentration was also associated with increased mortality among dialysis patients who were not receiving vitamins (Heinz et al., 2009). In addition, mitochondria have higher levels of several folate forms and tetrahydrofolate-synthesizing enzymes; folate deficiency impaired nuclear DNA and mitochondrial DNA synthesis, mitochondrial folate uptake, and enhanced mitochondrial oxidative decay, which may occur in hemodialysis patients.

Several studies have shown that folate deficiency is not observed in all patients on chronic hemodialysis (Tremblay et al., 2000; Coveney et al., 2010); although, blood folate loss can occur during the hemodialysis process (Tamura et al., 1996; Leblanc et al., 2000; Heinz et al., 2008). An inverse correlation between blood folate and total homocysteine concentrations has been shown (Koulouridis et al., 2001). This relationship between homocysteine and folate suggests that the concentrations of folate within the reference interval are inadequate for dialysis patients.

With regards to decreasing plasma folate concentration, it is strongly associated with increased homocysteine, TBARS, pro-inflammatory cytokines, and CD4/CD8 lymphocyte ratios (our unpublished observations). Also, a reduced folate concentration is inversely associated with colon tumorigenesis in these patients (Kaji et al., 2011). Plasma homocysteine concentrations are higher in dialysis patients; however, no significant inverse correlation between homocysteine and bone mineral density is observed (Kayabasi et al., 2010). By contrast, increased concentrations of homocysteine are associated with an increased risk fracture in hemodialysis patients (Jamal et al., 2005).

Chronic renal disease is associated with a relative resistance to the lowering effects of lowdose folate supplementation on homocysteine (Bostom et al., 1997). Folic acid supplementation (1-5 mg/day) may normalize plasma homocysteine levels in moderately hyperhomocysteinemic individuals with normal renal function; however, a similar effect has not been observed in ESRD patients (Tremblay et al., 2000). Supplementation with high dose of folate (> $5 \mathrm{mg}$ /day) significantly reduces plasma homocysteine in hemodialysis patients, with or without atherosclerosis (Stanford et al., 2000).

Hemodialysis patients who received daily supplements of $15 \mathrm{mg}$ of folic acid for 2 months had markedly increased in plasma folate concentrations and decreased blood total homocysteine, irrespective of their 5,10-methylene-tetrahydrofolate reductase (MTHFR) C677T genotypes (Billion et al., 2002). In hemodialysis patients who received oral supplementations of $15 \mathrm{mg} /$ day of folic acid, had significantly lower homocysteine concentrations and found no evidence of adverse effects (Bostom et al., 1996). Treatment with folic acid (10 mg/day) for 6 months have normalized plasma homocysteine concentrations, and significantly increased total plasma antioxidant capacity and decreased TBARS levels in these patients (Chiarello et al., 2003; Alvares Delfino et al., 2007). For hemodialysis patients who were given $15 \mathrm{mg}$ / day of 5-methyltetrahydrofolate for 12 weeks, increased plasma folate concentration and improved endothelial dysfunction were observed (Baragetti et al., 2007). On the other hand, intravenous 5-methyltetrahydrofolate $(50 \mathrm{mg} /$ day for 2-5 years) reduced inflammation status and prolonged survival rate in ESRD patients undergoing hemodialysis (Cianciolo et al., 2008). Low-dose intravenous folinic acid (1 $\mathrm{mg} /$ day, 3 times/week) for 3 months significantly reduced plasma homocysteine and MDA concentrations (Apeland et al., 2002). 
Routine supplementations of folic acid over long time periods should be considered in order to reduce homocysteine concentrations, may be more beneficial in minimizing uremic complications in hemodialysis patients.

\subsection{Vitamin B6}

Vitamin B6, a water-soluble vitamin, is an essential coenzyme for numerous biochemical pathways and is a potent antioxidant. Vitamin B6 is involved in lipid metabolism, nucleic acid and protein biosynthesis, and helps to maintain normal nerve function and the formation of red blood cells (Hisano et al., 2010). Vitamin B6 is also critically required for absorption of vitamin B12 and synthesis of niacin. Moreover, it may inhibit platelet aggregation, and ameliorate the development of diabetic neuropathy (Metz et al., 2003; Kobzar et al., 2009). By contrast, vitamin B6 deficiency impairs lymphocyte maturation, growth and proliferation, and antibody production; it suppresses the production of Th1 cytokines and, thus, promotes Th2 responses (Maggini et al., 2007).

Pyridoxal-5'-phosphate, the active moiety of vitamin B6, is significantly depleted in most chronic hemodialysis patients without supplementation and high-efficiency hemodialysis contributes to its depletion (Leblanc et al., 2000; Tremblay et al., 2000; Busch et al., 2010). In addition, these patients need to consume more vitamin B6 for hemoglobin synthesis during rHuEPO treatment, which result in vitamin B6 deficiency (Mydlik et al., 1997). Hyperhomocysteinemia may be also caused by reduced vitamin B6 concentrations. Blood cystathionine status is major indicator for the trans-sulfuration pathway of homocysteine, which has been shown to be dramatically increased in hemodialysis patients due to the inhibition of cystathionine catabolism by low blood vitamin B6 contents (Herrmann and Obeid, 2005). On the other hand, high concentrations of homocysteine in blood associated with an increased risk of cardiovascular disease, but no significant difference in the predialysis serum pyridoxal-5'-phosphate concentrations of patients with or without evidence of vascular disease (Leblanc et al., 2000).

There is increasing evidence that deficiency of vitamin B6 may cause hyperoxalemia and hyperoxaluria in dialysis patients; vitamin B6 treatment lower urinary oxalate excretion and inhibit calcium oxalate crystal formation (Chetyrkin et al., 2005; Mydlík and Derzsiová, 2010). In contrast, lower blood concentration of vitamin B6 was correlated with accumulation of the advanced glycation end-products (AGE) in hemodialysis patients (Busch et al., 2010). Increased oxidative stress by-product can induce calcium oxalate crystal aggregation and attachment in the renal tubules (Thamilselvan and Menon, 2005).

A previous study showed oral supplementation of folic acid ( $5 \mathrm{mg} /$ day for 14 days), but not vitamin B6 (40 mg) or B12 (1 mg), was very effective in lowering total homocysteine in healthy subjects. However, in dialysis patients require much more aggressive B-complex vitamins therapy to achieve the effect of lowering total plasma homocysteine (Bostom et al., 1996). These patients treatment with vitamin B supplements (15 mg of folic acid, $100 \mathrm{mg}$ of vitamin B6, and $1 \mathrm{mg}$ of vitamin B12/day for 4 weeks), but not vitamin B6 alone, have significantly decreasing total plasma homocysteine. Vitamin B supplementation $(40 \mathrm{mg}$ of folic acid, $100 \mathrm{mg}$ of pyridoxine hydrochloride, and $2 \mathrm{mg}$ of cyanocobalamin) decreased plasma homocysteine concentrations, but did not improve survival or reduce the incidence of vascular disease in those patients (Jamison et al., 2007). Increased intake of B-complex vitamins (5 mg of folic acid, $20 \mathrm{mg}$ of vitamin B6, and $50 \mu \mathrm{g}$ of vitamin B12) given 3 times per week for an average of 2 years did not reduce mortality and had no significant effects on 
the risk of cardiovascular events in patients with end-stage renal disease (Heinz et al., 2010). In contrast, high-dose intravenous B-complex vitamins (250 mg of vitamin B1, $250 \mathrm{mg}$ of B6, and $1500 \mu \mathrm{g}$ of B12; 3 times/week) reduced blood total homocysteine levels only when combined with $5 \mathrm{mg}$ of folate given orally (Sombolos et al., 2002). Other results indicate that the folate $(5 \mathrm{mg})$ and vitamin B6 (250 mg) supplementation, but not vitamin B6 alone, resulted in a reduction of homocysteine concentrations and improvement of the lipidemic profiles (LDL and HDL) in patients maintained with hemodialysis (Ziakka et al., 2001).

However, vitamin B6 (pyridoxine) supplementation (50 mg/day for 3-5 weeks) alone has been shown to improve the immune function of hemodialysis patients (Casciato et al., 1984). Vitamin B6 supplementation (60 mg/day for 4 weeks) was also effective in improving peripheral polyneuropathy symptoms of various etiologies, possibly because of the resistance to peripheral polyneuropathy that vitamin B6 provides for hemodialysis patients (Okada et al., 2000).

In summary, results above indicate that administrations of vitamin B6 and folic acid in combination are clinically beneficial for improving blood homocysteine status, lipid profile and peripheral polyneuropathy symptoms, and reducing calcium oxalate formation. The dose in 50 to $100 \mathrm{mg} /$ day of vitamin B6 can be of great therapeutic value in hemodialysis patients. However, daily consumption of large amounts of vitamin B6 supplements (> 100 mg) should be carefully considered.

\subsection{Vitamin B12}

Another essential micronutrient that is crucial for health is vitamin B12 (cobalamin), which is involved in one-carbon (methyl) metabolism. Two forms of vitamin B12, methylcobalamin and 5-deoxyadenosyl cobalamin, are commonly used by the human body. Cobalamin is required for the methionine synthase that catalyzes the conversion of homocysteine into methionine, and insufficient amounts will result in hyperhomocysteinemia (Green and Miller, 2007). In addition, cobalamin is required by L-methylmalonyl-CoA mutase that catalyzes the conversion of L-methylmalonyl-CoA to succinyl-CoA, thus maintaining methylmalonic acid within its normal range.

Vitamin B12 status is typically assessed by plasma or serum vitamin B12 concentrations. For adults, values below approximately $170-250 \mathrm{pg} / \mathrm{mL}$ indicate vitamin B12 deficiency (Institute of Medicine, 1998). An elevated homocysteine concentration (values $>13 \mu \mathrm{mol} / \mathrm{L}$ ) and increased methylmalonic acid also suggest vitamin B12 deficiency (De Vecchi et al., 2000; Andrès et al., 2007). In a vitamin B12-deficient state, the irreversible reaction that forms 5-methyl tetrahydrofolate results in a secondary folate deficiency with concomitant impairments in thymidine and purine synthesis, which can lead to alterations in immunoglobulin production (Maggini et al., 2007). Individuals with vitamin B12 deficiencies may also have anemia, gastrointestinal symptoms, or peripheral neuropathies (Marar et al., 2001). Evidence has accumulated in recent years that vitamin B12 supplementation has beneficial effects on cardiovascular disease, dementia and cognitive function, depression, and some cancers.

In chronic dialysis patients, markedly increased concentrations of methylmalonic acid and total homocysteine have been found (Herrmann and Obeid, 2005). Statistically significant correlations were observed between homocysteine and vitamin B12 concentrations (De Vecchi et al., 2000). The uptake of vitamin B12 by peripheral blood mononuclear cells from hemodialysis patients was lower than by cells from controls (Herrmann et al., 2001). 
Treatment with vitamin B12 and folic acid, but not vitamin B12 alone, appears to be effective for lowering the total plasma homocysteine concentration in hemodialysis patients who have either normal vitamin B12 concentrations or a deficiency (Pastore et al., 2006). In addition, adding vitamin B12 to a folate supplement can further enhance the reduction of plasma homocysteine, as compared to treatment with folate alone (Stopper et al., 2008). Oral supplementation with $15 \mathrm{mg} /$ day of folic acid together with $1 \mathrm{mg} /$ day of vitamin B12 was more effective for reducing homocysteine concentrations (Azadibakhsh et al., 2009). Further, genomic damage in the peripheral blood lymphocytes of dialysis patients due to oxidative stress can be ameliorated by supplementation with folic acid and vitamin B12, which is thought to contribute to homocystine reduction (Stopper et al., 2008).

Both folic acid and vitamin B12 supplements have desirable effects on blood homocysteine levels. However, a poor response to treatment with erythropoietin for renal anemia is common. Infections, oxidative stress, and inflammation have been shown to reduce the responsiveness to erythropoiesis- stimulating agents by increasing the release of proinflammatory cytokines (Stenvinkel, 2003). Oxidative stress and inflammation can be attenuated by vitamin B12 and folate supplementation. Whether vitamin B12 alone or in combination with folate is beneficial for altering erythropoiesis in hemodialysis patients may need further investigation.

\section{Other nutrients (substrates)}

\subsection{EPA and DHA}

A growing body of evidence suggests that the omega- 3 fatty acids eicosapentaenoic acid (EPA, 20:5n-3) and docosahexaenoic acid (DHA, 22:6n-3) have immune modulating, antiinflammatory, lipid-lowering, anti-arrhythmic, and anti-hypertensive effects (Kris-Etherton et al., 2002). Both EPA and DHA are present in mitochondrial membranes and are essential for mitochondrial function. It has been reported that omega-3 fatty acids could decrease the production of homocysteine; thus, they had a cardioprotective effect in patients with normal renal function (Pooya et al., 2010). Fish oil sources of EPA and DHA have also shown renal protective effects that prevented against the progression to chronic kidney disease in older adults (Lauretani et al., 2009). These could also significantly reduce inflammation, fibrosis and oxidative stress following renal injury (Soumura et al., 2010; Peake et al., 2011). Moreover, fish oil supplements (900 mg of EPA and $600 \mathrm{mg}$ of DHA/day for $1 \mathrm{month}$ ) may decrease urinary oxalate excretion and the risk of calcium oxalate crystallization attributable to an altered oxalate transporter activity (Siener et al., 2011).

Chronic hemodialysis patients reportedly have significantly low concentrations of EPA and DHA in the plasma and cell membranes (Saifullah et al., 2007; Nakamura et al., 2008; Madsen et al., 2011). This abnormal status may be attributed to the dialysis process, which can enhance oxidative stress and potentially increase omega-3 fatty acid peroxidation. In addition, these patients consumed lower amounts of dietary fish and, consequently, had suboptimal blood concentrations (Kutner et al., 2002; Friedman et al., 2006).

Short-term supplementation with fish oil (2.4 $\mathrm{g}$ of EPA and $1.2 \mathrm{~g}$ of DHA) could significantly increase the EPA and DHA contents in leukocytes phospholipids of hemodialysis patients within one week (Faber et al., 2011). After oral administration of EPA/DHA (2.7 g/day for 3 months), decreased lipid peroxidation and leukotriene B4 production in peripheral blood mononuclear cells were found for ESRD patients on hemodialysis (Taccone-Gallucci et al., 
2006). Patients who were administered supplements of fish oil (2.4 g/day) for 2 months had significantly decreased inflammation and increased insulin sensitivity, HDL-cholesterol, albumin, and hemoglobin (Perunicic-Pekovic et al., 2007; Rasic-Milutinovic et al., 2007). Significantly increased serum HDL-cholesterol and decreased triglyceride concentrations were also observed in hemodialysis patients who were administered fish oil $(2.4 \mathrm{~g})$ supplements for 3 months (Svensson et al., 2004).

Supplementation with fish oils (EPA+DHA, $2 \mathrm{~g} /$ day) also had a beneficial effect on plasma HDL and triglyceride concentrations in those patients with serum triglyceride levels $>200$ $\mathrm{mg} / \mathrm{dl}$ and total cholesterol $>220 \mathrm{mg} / \mathrm{dl}$ (Taziki et al., 2007). Further, EPA (1.8 g/day) or fish oil (1.3 g/day) treatments for 3 months remarkably reduced the increased plasma concentrations of remnant lipoproteins and triglycerides and prevented the peroxidation of LDL in dialysis patients (Ando et al., 1999; Saifullah et al., 2007). When hemodialysis patients were given low doses of fish oils (1.6-1.7 g/day), however, there were no significant improvements in their blood lipid profiles (Poulia et al., 2011), lipoprotein (a) (Beavers et al., 2009), or homocysteine concentrations (Rasmussen et al., 2010).

Uremic pruritus, also known the renal itch, is quite common in patients undergoing hemodialysis or peritoneal dialysis (50-90\%). The pathological processes that lead to uremic pruritus remain poorly understood, and there is no definitive treatment. Administration of fish oil (6 g/day for 8 weeks) could significantly decrease erythropoietin requirements (Jones and Kaiser, 2002) and improved the severity and distribution of uremic pruritus among hemodialysis patients (Peck et al., 1996). These authors speculated that the antiinflammatory and anti-proliferative effects of fish oils may have contributed to these symptoms' reversal.

Abundant evidence suggests that EPA/DHA exhibit powerful lipid-lowering and antiinflammatory capabilities, and are consequently involved with reduced uremic complications and an enhanced nutrition status in hemodialysis patients.

\subsection{Coenzyme Q10}

Coenzyme Q10 is a member of the ubiquinone family of compounds, which is found in virtually all cell membranes, mitochondria, and lipoproteins. Coenzyme Q10 is a vitaminlike substance that plays a crucial role in energy metabolism and in free radical scavenging (Thomas and Stocker, 2001). It is also recognized an obligatory cofactor for the functions of uncoupling proteins (Echtay et al., 2000).

Coenzyme Q10 has a direct anti-atherogenic property; oral coenzyme Q10 supplementation was shown to ameliorate cardiac contractility and endothelial dysfunction in patients with chronic heart failure (Littarru and Tiano, 2007). In addition, a recent study identified coenzyme Q10-sensitive genes that were regulated by peroxisome proliferator-activated receptor-alpha (PPAR $\alpha$ ) and were involved in cholesterol synthesis, lipoprotein metabolism, and inflammation (Schmelzer et al., 2010).

There is evidence to support the safety and efficacy of coenzyme Q10 in congestive heart failure, diabetes, atherosclerosis, hypertension, cardiomyopathies, migraine, and Parkinson's disease (Rosenfeldt et al., 2007; Nahas, 2008). Coenzyme Q10 supplementation may result in increased concentrations of coenzyme Q10 within circulating lipoproteins and increase the resistance of human LDL to oxidation (Littarru and Tiano, 2007). Coenzyme Q10 supplement (200 mg/day) improved blood pressure, and the endothelial functions of the conducting arteries of the peripheral circulation in dyslipidemia patients with type 2 
diabetes (Hodgson et al., 2002; Watts et al., 2002). A combination of orally given fenofibrate and coenzyme Q10 (200 mg/day) was effective for improving the endothelium-dependent and endothelium-independent vasodilator functions of the forearm microcirculation (Playford et al., 2003). Further, coenzyme Q10 attenuated elevated blood pressure, renal membrane phospholipid degradation, and enhanced renal phospholipase A2 due to its antioxidant and anti-inflammatory actions (Okamoto et al., 1991; Ishikawa et al., 2011).

Evidence has shown that high coenzyme Q10 contents in human renal tissues (Dallner and Sindelar, 2000). However, the plasma coenzyme Q10 and coenzyme Q10/LDL-cholesterol ratios in both conservative therapy and hemodialysis populations were markedly lower (Lippa et al., 2000). Plasma coenzyme Q10 concentrations were significantly decreased and MDA concentrations were increased (Gazdikova et al., 2000); reduced coenzyme Q10 status probably due to renal impairment and removal by dialyses. However, statins are widely used cholesterol-lowering medications that may decrease the endogenous synthesis of coenzyme Q10, and are consequently involved with reduced mitochondrial respiration and perhaps mitochondria and cell death (De Pinieux et al., 1996; Colquhoun et al., 2005).

Hemodialysis patients always have an impaired mitochondrial respiratory system, and this may contribute to enhance oxidative stress (Granata et al., 2009). It has been reported that coenzyme Q10 administration suppressed oxidative stress in hemodialysis patients (Sakata et al., 2008). Supplementation with coenzyme Q10 (100 mg/day) for 3 months reduced the serum lipoprotein (a) in hemodialysis patients who were treated with statins (Shojaei et al., 2011); decreased serum lipoprotein (a) attributed to inhibition of expression of lipoprotein(a) receptor by coenzyme Q10 (Singh and Niaz, 1999). Coenzyme Q10 supplementation (90-120 $\mathrm{mg} /$ day) significantly improved the peripheral circulation and decreased the plasma concentrations of TBARS and carbonyl protein in patients on hemodialysis or peritoneal dialysis (our unpublished observations), although we were unable to determine coenzyme Q10 status at baseline. There was significantly lower salivary secretion in hemodialysis patients (Gavaldá et al., 1999); administered supplemental coenzyme Q10 (100 mg/day for 1 month) to these patients can improve salivary secretion (Ryo et al., 2011). Nahas (2008) indicated that a typical dose of 60 to $120 \mathrm{mg}$ 1-3 times daily was not associated with any serious risks. In fact, the toxicity of higher doses of coenzyme Q10 has not been encountered in clinical use.

Low coenzyme Q10 status and increased oxidative stress in chronic dialysis patients may be ameliorated by coenzyme Q10 administration, which, therefore, can be considered as a complementary treatment. Although promising, administrations of coenzyme Q10 may improve peripheral circulation status and lipid profile, prevent against cardiovascular disease and neurodegenerative disease in patients undergoing hemodialysis require further study.

\subsection{Probiotics, prebiotics and synbiotics}

Chronic gastrointestinal symptoms are the most common in ESRD patients who are treated by hmodialysis or peritoneal dialysis. Disturbances in gastric and small intestinal motileity, small intestine bacterial overgrowth, gastric hypochlorhydria, diarrhea, abdominal pain, and irritable bowel syndrome are symptoms typically seen in these patients (Cano et al., 2007). The pathogenesis of these symptoms is probably multifactorial, and has also been attributed to changes in the small intestine microflora (Strid et al., 2003). It has been suggested that uremic toxins, commonly used medications, complications, and changes in dietary patterns have major influences on the microflora of the small intestine (Evenepoel et 
al., 2009; Shu et al., 2009). Further, an abnormal distribution of microflora in the gastrointestinal tract can result in gastrointestinal permeability and inflammation. Oxidative stress and malnutrition frequently occur in people who suffer from gastrointestinal disturbances.

In addition to these considerations, uremic toxins include low-molecular weight solutes, medium-sized molecules (peptides and proteins), and protein-bound, low-molecular weight solutes. With regard to the latter, such as indoxyl sulfate and p-cresyl sulfate (originating from intestinal bacterial fermentation end-products of tyrosine and tryptophan), these cannot be efficiently removed by hemodialysis, even with a high-flux membrane (Niwa, 2011). Accumulation of these uremic toxins induces free radical production, and increases the expressions of transforming growth factor- $\beta 1$, tissue inhibitor of metalloproteinase- 1 and proalpha1(I) collagen; therefore, they play an important role in the development of cardiovascular disease and can promote the progression of renal dysfunction (Niwa, 2010).

Some studies in humans have indicated the potential efficacy of probiotic, prebiotic, or synbiotic preparations for gastrointestinal diseases (Madsen et al., 2001). Probiotics are defined as viable micro- organisms for which sufficient quantities can reach the intestine in an active state and exert beneficial health effects. Prebiotics are non-digestible food ingredients that are metabolized by the probiotics. Synergistically acting combinations of probiotics and prebiotics are designated synbiotics.

The reported beneficial effects of these preparations include stimulation of intestinal motility and intestinal immunity, recovery of a disturbed gut mucosa barrier, elimination of toxins and potential pathogens, the release of nutrients, antioxidants and growth factors, stimulation of mineral absorption, and reduced colonic transit times via the normalization of altered intestinal microflora (Madsen et al., 2001; Singhi and Baranwal, 2008). In recent years, the prebiotic oligo-fructose-enriched inulin was shown to reduce urinary p-cresyl sulfate excretion in healthy volunteers (De Preter et al., 2007). The same authors also demonstrated that oligo-fructose-inulin significantly reduced p-cresyl sulfate generation rates and serum concentrations in hemodialysis patients (Meijers et al., 2010).

However, an oral preparation of lactic acid bacteria did not reduce serum p-cresol concentrations in hemodialysis patients (Hida et al., 1996). Interestingly, the results of our preliminary study showed that synbiotics may be beneficial for decreased bacterial overgrowth and normal motility patterns in patients undergoing peritoneal dialysis and hemodialysis.

Intestinal therapeutic interventions with probiotics and prebiotics have provided some clinical benefits, but these have not been exhaustively studied in ESRD patients on hemodialysis or peritoneal dialysis. Nonetheless, it will be important to determine which probiotic genera and species possess beneficial traits, in addition to finding the optimal doses and possible synergistic combinations.

\section{Conclusion}

Renal dialysis patients appear to be prone to certain degrees of deficiencies for a number of micronutrients (Zn, Se, vitamin C, E, folate, B6, and B12) and nutritional substrates (coenzyme Q10 and EPA/DHA). This could be due to the significant losses of these factors in these patients or to their high needs. Increased oxidative stress and pro-inflammatory cytokines are important targets for nutritional and pharmacologic therapy for ESRD patients 
who are undergoing hemodialysis; prolonged oxidative stress and pro-inflammatory cytokine production can exacerbate the severity of uremic complications and inadequacy residual renal function. These clinical features may be ameliorated by the use of supplements of these micronutrients. Probiotics and prebiotics may also provide benefits to these patients. Their use is not always a standard of care for hemodialysis patients. Therefore, uncertainty has arisen as to whether or not nutraceutical interventions are needed by hemodialysis patients.

\section{References}

Abdollahzad H, Eghtesadi S, Nourmohammadi I, Khadem-Ansari M, Nejad-Gashti H, Esmaillzadeh A. (2009). Effect of vitamin C supplementation on oxidative stress and lipid profiles in hemodialysis patients. Int J Vitam Nutr Res, 79(5-6):281-287.

Adamowicz A, Trafikowska U, Trafikowska A, Zachara B, Manitius J. (2002). Effect of erythropoietin therapy and selenium supplementation on selected antioxidant parameters in blood of uremic patients on long-term hemodialysis. Med Sci Monit, 8(3):CR202-205.

Alvares Delfino VD, de Andrade Vianna AC, Mocelin AJ, Barbosa DS, Mise RA, Matsuo T. (2007). Folic acid therapy reduces plasma homocysteine levels and improves plasma antioxidant capacity in hemodialysis patients. Nutrition, 23(3):242-247.

Ando M, Sanaka T, Nihei H. (1999). Eicosapentanoic acid reduces plasma levels of remnant lipoproteins and prevents in vivo peroxidation of LDL in dialysis patients. J Am Soc Nephrol, 10(10):2177-2184.

Andrès E, Federici L, Affenberger S, Vidal-Alaball J, Loukili NH, Zimmer J, et al. (2007). B12 deficiency: a look beyond pernicious anemia. J Fam Pract, 56(7):537-542.

Andrew NH, Engel B, Hart K, Passey C, Beaden S. (2008). Micronutrient intake in haemodialysis patients. J Human Nutr Diet, 21:375-376.

Apeland T, Mansoor MA, Seljeflot I, Brønstad I, Gøransson L, Strandjord RE. (2002). Homocysteine, malondialdehyde and endothelial markers in dialysis patients during low-dose folinic acid therapy. J Intern Med, 252(5):456-464.

Ardalan MR, Tubbs RS, Shoja MM. (2007). Vitamin E and selenium co-supplementation attenuates oxidative stress in haemodialysis patients receiving intra-dialysis iron infusion. Nephrol Dial Transplant, 22(3):973-975.

Attallah N, Osman-Malik Y, Frinak S, Besarab A. (2006). Effect of intravenous ascorbic acid in hemodialysis patients with EPO-hyporesponsive anemia and hyperferritinemia. Am J Kidney Dis, 47(4):644-654.

Azadibakhsh N, Hosseini RS, Atabak S, Nateghiyan N, Golestan B, Rad AH. (2009). Efficacy of folate and vitamin B12 in lowering homocysteine concentrations in hemodialysis patients. Saudi J Kidney Dis Transpl, 20(5):779-788.

Bachman J, Tepel M, Raidt H, Riezer R, Grafe U, Langer K, Zidek W. (1995). Hyperhomocysteinemia and the risk of vascular disease in hemodialysis patients. $J$ Am Soc Nephrol, 6:121-125.

Baragetti I, Raselli S, Stucchi A, Terraneo V, Furiani S, Buzzi L, Garlaschelli K, Alberghini E, Catapano AL, Buccianti G. (2007). Improvement of endothelial function in uraemic 
patients on peritoneal dialysis: a possible role for 5-MTHF administration. Nephrol Dial Transplant, 22(11):3292-3297.

Beavers KM, Beavers DP, Bowden RG, Wilson RL, Gentile M. (2009). Effect of over-thecounter fish-oil administration on plasma $\mathrm{Lp}(\mathrm{a})$ levels in an end-stage renal disease population. J Ren Nutr, 19(6): 443-449.

Bevc S, Hojs R, Ekart R, Hojs-Fabjan T.et al., (2006). Atherosclerosis in hemodialysis patients: traditional and nontraditional risk factors. Acta Dermatovenerol Alp Panonica Adriat, 15(4):151-157.

Bilgic A, Akgul A, Sezer S, Arat Z, Ozdemir FN, Haberal M. (2007). Nutritional status and depression, sleep disorder, and quality of life in hemodialysis patients. J Ren Nutr, 17(6):381-388.

Billion S, Tribout B, Cadet E, Queinnec C, Rochette J, Wheatley P, Bataille P. (2002). Hyperhomocysteinaemia, folate and vitamin B12 in unsupplemented haemodialysis patients: effect of oral therapy with folic acid and vitamin B12. Nephrol Dial Transplant, 17(3):455-461.

Bo S, Durazzo M, Gambino R, Berutti C, Milanesio N, Caropreso A, Gentile L, Cassader M, Cavallo-Perin P, Pagano G. (2008). Associations of dietary and serum copper with inflammation, oxidative stress, and metabolic variables in adults. J Nutr, 138:305310.

Boaz M, Smetana S, Weinstein T, Matas Z, Gafter U, Iaina A, Knecht A, Weissgarten Y, Brunner D, Fainaru M, et al. (2000). Secondary prevention with antioxidants of cardiovascular disease in end stage renal disease (SPACE): randomised placebocontrolled trial. Lancet, 356(9237):1213-1218.

Bober J, Kwiatkowska E, Kedzierska K, Olszewska M, Gołebiewska E, Stachowska E, Kucharska E, Ciechanowski K, Chlubek D. (2007). Influence of glucose in the dialysate on the activity of erythrocyte-glutathione-peroxidase and blood selenium concentration in hemodialyzed patients. Arch Med Res, 38(3):330-336.

Böhm V, Tiroke K, Schneider S, Sperschneider H, Stein G, Bitsch R. (1997). Vitamin C status of patients with chronic renal failure, dialysis patients and patients after renal transplantation. Int J Vitam Nutr Res, 67(4):262-266.

Bostom AG, Shemin D, Verhoef P, Nadeau MR, Jacques PF, Selhub J, Dworkin L, Rosenberg IH. (1997). Elevated fasting total plasma homocysteine levels and cardiovascular disease outcomes in maintenance dialysis patients: A prospective study. Arterioscler Thromb Vasc Biol, 17:2554-2558.

Busch M, Göbert A, Franke S, Ott U, Gerth J, Müller A, Stein G, Bitsch R, Wolf G. (2010). Vitamin B6 metabolism in chronic kidney disease--relation to transsulfuration, advanced glycation and cardiovascular disease. Nephron Clin Pract, 114(1):c38-46.

Bostom AG, Shemin D, Lapane KL, Hume AL, Yoburn D, Nadeau MR, Bendich A, Selhub J, Rosenberg IH. (1996). High dose B-vitamin treatment of hyperhomocysteinemia in dialysis patients. Kidney Int, 49(1):147-152.

Candan F, Gültekin F, Candan F. (2002). Effect of vitamin C and zinc on osmotic fragility and lipid peroxidation in zinc-deficient haemodialysis patients. Cell Biochem Funct. 20(2):95-98. 
Cano AE, Neil AK, Kang JY, Barnabas A, Eastwood JB, Nelson SR, Hartley I, Maxwell D. (2007). Gastrointestinal symptoms in patients with end-stage renal disease undergoing treatment by hemodialysis or peritoneal dialysis. Am J Gastroenterol, 102(9):1990-1997.

Casciato DA, McAdam LP, Kopple JD, Bluestone R, Goldberg LS, Clements PJ, Knutson DW. (1984). Immunologic abnormalities in hemodialysis patients: improvement after pyridoxine therapy. Nephron, 38(1):9-16.

Celiker A, Giray B, Başay T, Oner L. (2001). The effect of recombinant human erythropoietin on serum selenium levels in hemodialysis patients. J Trace Elem Med Biol, 15(4):215220.

Chan D, Irish A, Croft KD, Dogra G. (2006). Effect of ascorbic acid supplementation on plasma isoprostanes in haemodialysis patients. Nephrol Dial Transplant, 21(1):234235

Chen YH, Shi W, Liang XL, Liang YZ, Fu X. (2011). Effect of blood sample type on the measurement of advanced oxidation protein products as a biomarker of inflammation and oxidative stress in hemodialysis patients. Biomarkers, 16(2):129135.

Chetyrkin SV, Kim D, Belmont JM, Scheinman JI, Hudson BG, Voziyan PA. (2005). Pyridoxamine lowers kidney crystals in experimental hyperoxaluria: a potential therapy for primary hyperoxaluria. Kidney Int, 67(1):53-60.

Chevalier CA, Liepa G, Murphy MD, Suneson J, Vanbeber AD, Gorman MA, Cochran C. (2002). The effects of zinc supplementation on serum zinc and cholesterol concentrations in hemodialysis patients. J Ren Nutr, 12(3):183-189.

Chiarello PG, Vannucchi MT, Moysés Neto M, Vannucchi H. (2003). Hyperhomocysteinemia and oxidative stress in hemodialysis: effects of supplementation with folic acid. Int J Vitam Nutr Res, 73(6):431-438.

Chien CT, Chang WT, Chen HW, Wang TD, Liou SY, Chen TJ, Chang YL, Lee YT, Hsu SM. (2004). Ascorbate supplement reduces oxidative stress in dyslipidemic patients undergoing apheresis. Arterioscler Thromb Vasc Biol, 24(6): 1111-1117.

Chiu YL, Chen HY, Chuang YF, Hsu SP, Lai CF, Pai MF, Yang SY, Peng YS. (2008). Association of uraemic pruritus with inflammation and hepatitis infection in haemodialysis patients. Nephrol Dial Transplant, 23(11):3685-3689.

Cianciolo G, La Manna G, Colì L, Donati G, D'Addio F, Persici E, Comai G, Wratten M, Dormi A, Mantovani V, Grossi G, Stefoni S. (2008). 5-methyltetrahydrofolate administration is associated with prolonged survival and reduced inflammation in ESRD patients. Am J Nephrol, 28(6):941-948.

Colquhoun DM, Jackson R, Walters M, Hicks BJ, Goldsmith J, Young P, Strakosch C, Kostner KM. (2005). Effects of simvastatin on blood lipids, vitamin E, coenzyme Q10 levels and left ventricular function in humans. Eur J Clin Invest, 35(4):251-258.

Coveney N, Polkinghorne KR, Linehan L, Corradini A, Kerr PG. (2010). Water-soluble vitamin levels in extended hours hemodialysis. Hemodial Int, [Epub ahead of print]

Curhan GC, Willett WC, Rimm EB, Stampfer MJ. (1996). A prospective study of the intake of vitamins C and B6, and the risk of kidney stones in men, J Urol, 155(6):1847-1851. 
Curhan GC, Willett WC, Speizer FE, Stampfer MJ. (1999). Intake of vitamins B6 and C and the risk of kidney stones in women. J Am Soc Nephrol, 10(4):840-845.

Dallner G, Sindelar PJ. (2000). Regulation of ubiquinone metabolism. Free Radic Biol Med, 29(3-4): 285-294.

Dashti-Khavidaki S, Khalili H, Vahedi SM, Lessan-Pezeshki M. (2010). Serum zinc concentrations in patients on maintenance hemodialysis and its relationship with anemia, parathyroid hormone concentrations and pruritus severity. Saudi J Kidney Dis Transpl, 21(4):641-645.

Davis CD, Johnson WT. (2001). Dietary copper and dimethylhydrazine affect protein kinase $\mathrm{C}$ isozyme protein and mRNA expression and the formation of aberrant crypts in colon of rats. Biofactors, 15(1): 11-26.

Davis CD and Uthus EO. (2004). DNA methylation, cancer susceptibility, and nutrient interactions. Exp Biol Med (Maywood), 229(10):988-995.

De Pinieux G, Chariot P, Ammi-Saïd M, Louarn F, Lejonc JL, Astier A, Jacotot B, Gherardi R. (1996). Lipid-lowering drugs and mitochondrial function: effects of HMG-CoA reductase inhibitors on serum ubiquinone and blood lactate/pyruvate ratio. $\mathrm{Br} \mathrm{J}$ Clin Pharmacol, 42(3):333-337.

De Preter V, Vanhoutte T, Huys G, Swings J, De Vuyst L, Rutgeerts P, Verbeke K. (2007). Effects of Lactobacillus casei Shirota, Bifidobacterium breve, and oligofructoseenriched inulin on colonic nitrogen-protein metabolism in healthy humans. Am J Physiol Gastrointest Liver Physiol, 292(1): G358- G368.

De Vecchi AF, Bamonti-Catena F, Finazzi S, Campolo J, Taioli E, Novembrino C, Colucci P, Accinni R, De Franceschi M, Fasano MA, Maiolo AT. (2000). Homocysteine, vitamin B12, and serum and erythrocyte folate in peritoneal dialysis and hemodialysis patients. Perit Dial Int, 20(2):169-173.

Deved V, Poyah P, James MT, Tonelli M, Manns BJ, Walsh M, Hemmelgarn BR. (2009). Ascorbic acid for anemia management in hemodialysis patients: a systematic review and meta-analysis. Am J Kidney Dis, 54(6):1089-1097.

Deicher R, Ziai F, Bieglmayer C, Schillinger M, Hörl WH. (2005). Low total vitamin C plasma level is a risk factor for cardiovascular morbidity and mortality in hemodialysis patients. J Am Soc Nephrol, 16(6):1811-1818.

DiSilvestro, RA. (2005). Selenium. In: "Handbook of Minerals as Nutritional Supplements" (ed. DiSilvestro RA). Boca Raton: CRC Press. pp. 193-218.

Dursun E, Ozben T, Süleymanlar G, Dursun B, Yakupoglu G. (2002). Effect of hemodialysis on the oxidative stress and antioxidants. Clin Chem Lab Med, 40(10):1009-1013.

Echtay KS, Winkler E, Klingenberg M. (2000). Coenzyme Q is an obligatory cofactor for uncoupling protein function. Nature, 408(6812):609-613.

Eiselt J, Racek J, Opatrný K Jr, Trefil L, Stehlík P. (2006). The effect of intravenous iron on oxidative stress in hemodialysis patients at various levels of vitamin C. Blood Purif, 24(5-6):531-537.

Evenepoel P, Meijers BK, Bammens BR, Verbeke K. (2009). Uremic toxins originating from colonic microbial metabolism. Kidney Int Suppl, 76 (Suppl 114): S12-S19 .

Faber J, Berkhout M, Vos AP, Sijben JW, Calder PC, Garssen J, van Helvoort A. (2011). Supplementation with a Fish Oil-Enriched, High-Protein Medical Food Leads to 
Rapid Incorporation of EPA into White Blood Cells and Modulates Immune Responses within One Week in Healthy Men and Women. J Nutr, 141(5):964-970.

Ferms GAA. (2003). Differential effects of statins on serum CRP levels: implications of recent clinical trials. Atherosclerosis, 169(2):349-352.

Ferretti G, Bacchetti T, Masciangelo S, Pallotta G. (2008). Lipid peroxidation in hemodialysis patients: effect of vitamin C supplementation. Clin Biochem, 41(6):381-386.

Filiopoulos V, Hadjiyannakos D, Takouli L, Metaxaki P, Sideris V, Vlassopoulos D. (2009). Inflammation and oxidative stress in end-stage renal disease patients treated with hemodialysis or peritoneal dialysis. Int J Artif Organs, 32(12):872-882.

Finkelstein FO, Juergensen P, Wang S, Santacroce S, Levine M, Kotanko P, Levin NW, Handelman GJ. (2011). Hemoglobin and plasma vitamin C levels in patients on peritoneal dialysis. Perit Dial Int, 31(1):74-79.

Ford ES. (2000). Serum copper concentration and coronary heart disease among US adults. Am J Epidemiol, 151(12):1182-1188.

Friedman AN, Moe SM, Perkins SM, Li Y, Watkins BA. (2006). Fish consumption and omega-3 fatty acid status and determinants in long-term hemodialysis. Am J Kidney Dis, 47(6):1064-1071.

Fujishima Y, Ohsawa M, Itai K, Kato K, Tanno K, Turin TC, Onoda T, Endo S, Okayama A, Fujioka T. (2011b). Serum selenium levels are inversely associated with death risk among hemodialysis patients. Nephrol Dial Transplant, [Epub ahead of print]

Fujishima Y, Ohsawa M, Itai K, Kato K, Tanno K, Turin TC, Onoda T, Endo S, Okayama A, Fujioka T. (2011a). Serum selenium levels in hemodialysis patients are significantly lower than those in healthy controls. Blood Purif, 32(1):43-47.

Fukushima T, Horike H, Fujiki S, Kitada S, Sasaki T, Kashihara N. (2009). Zinc deficiency anemia and effects of zinc therapy in maintenance hemodialysis patients. Ther Apher Dial, 13(3):213-219.

Fumeron C, Nguyen-Khoa T, Saltiel C, Kebede M, Buisson C, Drüeke TB, Lacour B, Massy ZA. (2005). Effects of oral vitamin $C$ supplementation on oxidative stress and inflammation status in haemodialysis patients. Nephrol Dial Transplant, 20(9):18741879 .

Gavaldá C, Bagán J, Scully C, Silvestre F, Milián M, Jiménez Y. (1999). Renal hemodialysis patients: oral, salivary, dental and periodontal findings in 105 adult cases. Oral Dis, 5(4):299-302.

Gazdikova K, Gvozdjakova A, Kucharska J, Spustova V, Braunova Z, Dzurik R. (2000). Malondialdehyde and selected antioxidant plasma levels in conservatively treated patients with kidney diseases. Bratisl Lek Listy, 101(9):490-494.

Ghayour-Mobarhan M, Taylor A, Kazemi-Bajestani SM, Lanham-New S, Lamb DJ, Vaidya N, Livingstone C, Wang T, Ferns GA. (2008). Serum zinc and copper status in dyslipidaemic patients with and without established coronary artery disease. Clin Lab, 54(9-10):321-329.

Girelli D, Olivieri O, Stanzial AM, Azzini M, Lupo A, Bernich P, Menini C, Gammaro L, Corrocher R. (1993). Low platelet glutathione peroxidase activity and serum selenium concentration in patients with chronic renal failure: relations to dialysis treatments, diet and cardiovascular complications. Clin Sci (Lond), 84(6):611-617. 
Granata S, Zaza G, Simone S, Villani G, Latorre D, Pontrelli P, Carella M, Schena FP, Grandaliano G, Pertosa G. (2009). Mitochondrial dysregulation and oxidative stress in patients with chronic kidney disease. BMC Genomics, 10:388.

Green R, Miller JW. (2007). Vitamin B12. In: "Handbook of Vitamins". (eds. Zempleni J, Rucker RB, McCormick DB, Suttie JW). Boca Raton: CRC Press. pp. 413-457.

Grzegorzewska AE, Mariak I. (2001). Zinc as a marker of nutrition in continuous ambulatory peritoneal dialysis patients. Adv Perit Dial, 17(1):223-229

Guo CH, Ko WS, Chen PC, Hsu GSW, Lin CY, Wang CL. (2009). Alterations of trace elements and oxidative stress in uremic patients with dementia. Biol Trace Elem Res, 131(1):13-24.

Guo CH, Wang CL, Chen PC, Yang TC. (2010). Linkage of some trace elements, peripheral blood lymphocytes, inflammation, and oxidative stress in patients undergoing either hemodialysis or peritoneal dialysis. Perit Dial Int [Epub ahead of print]

Guo CH, Chen PC, Yeh MW, Hsiung DY, Wang CL. (2011). Cu/Zn ratios are associated with nutritional status, oxidative stress, inflammation, and immune abnormalities in patients on peritoneal dialysis. Clin Biochem, 44(4): 275-280.

Haase H, Rink L. (2009). The immune system and the impact of zinc during aging. Immun Ageing, 6:9.

Handelman GJ. (2007). Newer strategies for anemia prevention in hemodialysis. Int J Artif Organs, 30(11):1014-9.

Heinz J, Domröse U, Westphal S, Luley C, Neumann KH, Dierkes J. (2008). Washout of water-soluble vitamins and of homocysteine during haemodialysis: effect of highflux and low-flux dialyser membranes. Nephrology (Carlton), 13(5):384-389.

Heinz J, Kropf S, Domröse U, Westphal S, Borucki K, Luley C, Neumann KH, Dierkes J. (2010). B vitamins and the risk of total mortality and cardiovascular disease in endstage renal disease: results of a randomized controlled trial. Circulation, 121(12):1432-1438.

Heinz J, Kropf S, Luley C, Dierkes J. (2009). Homocysteine as a risk factor for cardiovascular disease in patients treated by dialysis: a meta-analysis. Am J Kidney Dis, 54(3):478489 .

Herrmann W, Obeid R. (2005). Hyperhomocysteinemia and response of methionine cycle intermediates to vitamin treatment in renal patients. Clin Chem Lab Med, 43(10):1039-1047.

Herrmann W, Schorr H, Geisel J, Riegel W. (2001). Homocysteine, cystathionine, methylmalonic acid and B-vitamins in patients with renal disease. Clin Chem Lab Med, 39(8):739-746.

Hida M, Aiba Y, Sawamura S, Suzuki N, Satoh T, Koga Y. (1996). Inhibition of the accumulation of uremic toxins in the blood and their precursors in the feces after oral administration of Lebenin, a lactic acid bacteria preparation, to uremic patients undergoing hemodialysis. Nephron, 74(2): 349-355

Himmelfarb J. (2005). Relevance of oxidative pathways in the pathophysiology of chronic kidney disease. Cardiol Clin, 23(3):319-330. 
Himmelfarb J, Phinney S, Ikizler TA, Kane J, McMonagle E, Miller G. (2007). Gammatocopherol and docosahexaenoic acid decrease inflammation in dialysis patients. $J$ Ren Nutr, 17(5):296-304.

Himmelfarb J. (2008). Oxidative stress in hemodialysis. Contrib Nephrol, 161:132-137.

Hisano M, Suzuki R, Sago H, Murashima A, Yamaguchi K. (2010). Vitamin B6 deficiency and anemia in pregnancy. Eur J Clin Nutr, 64(2):221-223.

Hodgson JM, Watts GF, Playford DA, Burke V, Croft KD. (2002). Coenzyme Q10 improves blood pressure and glycaemic control: a controlled trial in subjects with type 2 diabetes. Eur J Clin Nutr, 56(11):1137-1142.

Hodkova M, Dusilova-Sulkova S, Kalousova M, Soukupova J, Zima T, Mikova D, Malbohan IM, Bartunkova J. (2006). Influence of oral vitamin E therapy on microinflammation and cardiovascular disease markers in chronic hemodialysis patients. Ren Fail, 28(5):395-399.

Koh JM, Lee YS, Kim YS, Kim DJ, Kim HH, Park JY, Lee KU, Kim GS. (2006). Homocysteine enhances bone resorption by stimulation of osteoclast formation and activity through increased intracellular ROS generation. J Bone Miner Res, 21(7):1003-1011.

Institute of Medicine. Food and Nutrition Board. Dietary Reference Intakes: Thiamin, Riboflavin, Niacin, Vitamin B6, Folate, Vitamin B12, Pantothenic Acid, Biotin, and Choline. Washington, DC: National Academy Press, 1998.

Ishikawa A, Kawarazaki H, Ando K, Fujita M, Fujita T, Homma Y. (2011). Renal preservation effect of ubiquinol, the reduced form of coenzyme Q10. Clin Exp Nephrol, 15(1):30-33.

Islam KN, O'Byrne D, Devaraj S, Palmer B, Grundy SM, Jialal I. (2000). Alpha-tocopherol supplementation decreases the oxidative susceptibility of LDL in renal failure patients on dialysis therapy. Atherosclerosis, 150(1):217-224.

Jakubowski H. (2008). The pathophysiological hypothesis of homocysteine thiolactonemediated vascular disease. J Physiol Pharmacol, 59(Suppl 9):155-167.

Jalali GR, Roozbeh J, Mohammadzadeh A, Sharifian M, Sagheb MM, Hamidian Jahromi A, Shabani S, Ghaffarpasand F, Afshariani R. (2010). Impact of oral zinc therapy on the level of sex hormones in male patients on hemodialysis. Ren Fail, 32(4):417-419.

Jamal SA, Leiter RE, Bauer DC. (2005). Hyperhomocysteinaemia and aortic calcification are associated with fractures in patients on haemodialysis. QAM 98(8):575-579.

Jamison RL, Hartigan P, Kaufman JS, Goldfarb DS, Warren SR, Guarino PD, Gaziano JM. (2007). Effect of homocysteine lowering on mortality and vascular disease in advanced chronic kidney disease and end-stage renal disease: a randomized controlled trial. JAMA. 298(10):1163-1170.

Jauréguy M, Choukroun G. (2006). Factors affecting the response to erythropoiesisstimulating agents. Nephrol Ther, 2 (Suppl 4):S274-282.

Jern NA, VanBeber AD, Gorman MA, Weber CG, Liepa GU, Cochran CC. (2000). The effects of zinc supplementation on serum zinc concentration and protein catabolic rate in hemodialysis patients. J Ren Nutr, 10(3):148-153.

Jilani T, Iqbal MP. (2011). Does vitamin E have a role in treatment and prevention of anemia? Pak J Pharm Sci, 24(2):237-42. 
Jones WL, Kaiser SP. (2002). Pilot study: An emulsified fish oil supplement significantly improved C-reactive protein, hemoglobin, albumin and urine output in chronic hemodialysis volunteers. JANA. 5:45-50.

Kaji E, Kato J, Saito S, Harada K, Kuwaki K, Tatsukawa M, Morikawa T, Hiraoka S, Matsushima H, Yamamoto K. (2011). Serum folate and homocysteine levels are associated with colon tumorigenesis in end-stage renal disease patients. Nutr Cancer. 63(2):202-211.

Kamgar M, Zaldivar F, Vaziri ND, Pahl MV. (2009). Antioxidant therapy does not ameliorate oxidative stress and inflammation in patients with end-stage renal disease. J Natl Med Assoc, 101:336-344.

Kayabasi H, Sit D, Atay AE, Yilmaz Z, Kadiroglu AK, Yilmaz ME. (2010). Parameters of oxidative stress and echocardiographic indexes in patients on dialysis therapy. Ren Fail, 32(3):328-334

Kinsman GD, Howard AN, Stone DL, Mullins PA. (1990). Studies in copper status and atherosclerosis. Biochem Soc Trans, 1:1186

Kirmizis D, Papagianni A, Belechri AM, Memmos D. (2010). Effects of vitamin E-coated membrane dialyser on markers of oxidative stress and inflammation in patients on chronic haemodialysis. Nephrol Dial Transplant, [Epub ahead of print]

Kris-Etherton PM, Harris WS, Appel LJ. (2002). Fish consumption, fish oil, omega-3 fatty acids, and cardiovascular disease. Circulation, 106(21):2747-2757.

Kobzar G, Mardla V, Rätsep I, Samel N. (2009). Effect of vitamin B(6) vitamers on platelet aggregation. Platelets. 20(2):120-124.

Kocabaş CN, Adalioglu G, Coşkun T, Tuncer A, Sekerel BE. (2006). The relationship between serum selenium levels and frequent wheeze in children. Turk J Pediatr, 48(4): 308312

Koh JM, Lee YS, Kim YS, Kim DJ, Kim HH, Park JY, Lee KU, Kim GS. (2006). Homocysteine enhances bone resorption by stimulation of osteoclast formation and activity through increased intracellular ROS generation. J Bone Miner Res, 21(7):1003-1011.

Koulouridis E, Tzilianos M, Katsarou A, Costimba I, Klonou E, Panagiotaki E, Georgalidis C, Krokida A, Delaportas N, Lachanas A, Karaliotas G, Kaliolia I. (2001). Homocysteine and C-reactive protein levels in haemodialysis patients. Int Urol Nephrol. 33(2):207-215.

Kreft B, Fischer A, Krüger S, Sack K, Kirchner H, Rink L. (2000). The impaired immune response to diphtheria vaccination in elderly chronic hemodialysis patients is related to zinc deficiency. Biogerontology, 1(1):61-66.

Kupka R, Msamanga GI, Spiegelman D, Morris S, Mugusi F, Hunter DJ, Fawzi WW. (2004). Selenium status is associated with accelerated HIV disease progression among HIV-1-infected pregnant women in Tanzania. J Nutr, 134(10): 2556-2560

Kutner NG, Clow PW, Zhang R, Aviles X. (2002). Association of fish intake and survival in a cohort of incident dialysis patients. Am J Kidney Dis, 39(5):1018-1024.

Lauretani F, Maggio M, Pizzarelli F, Michelassi S, Ruggiero C, Ceda GP, Bandinelli S, Ferrucci L. (2009). Omega-3 and renal function in older adults. Curr Pharm Des, 15(36):4149-4156. 
Leblanc M, Pichette V, Geadah D, Ouimet D. (2000). Folic acid and pyridoxal-5'-phosphate losses during high-efficiency hemodialysis in patients without hydrosoluble vitamin supplementation. J Ren Nutr, 10(4):196-201.

Linus Pauling Institute. http://lpi.oregonstate.edu/infocenter/vitamins/vitaminC/

Lippa S, Colacicco L, Bondanini F, Callà C, Gozzo ML, Ciccariello M, Angelitti AG. (2000). Plasma levels of coenzyme $\mathrm{Q}(10)$, vitamin $\mathrm{E}$ and lipids in uremic patients on conservative therapy and hemo- dialysis treatment: some possible biochemical and clinical implications. Clin Chim Acta, 292(1-2): 81-91.

Littarru GP, Tiano L. (2007). Bioenergetic and antioxidant properties of coenzyme Q10: recent developments. Mol Biotechnol, 37(1):31-37.

Liuzzi JP, Lichten LA, Rivera S, Blanchard RK, Aydemir TB, Knutson MD, Ganz T, Cousins RJ. (2005). Interleukin-6 regulates the zinc transporter Zip14 in liver and contributes to the hypozincemia of the acute-phase response. Proc Natl Acad Sci USA, 102:68436848 .

Madsen T, Christensen JH, Svensson M, Witt PM, Toft E, Schmidt EB. (2011). Marine n-3 poly- unsaturated fatty acids in patients with end-stage renal failure and in subjects without kidney disease: a comparative study. J Ren Nutr. 21(2):169-175.

Maggini S, Wintergerst ES, Beveridge S, Hornig DH. (2007). Selected vitamins and trace elements support immune function by strengthening epithelial barriers and cellular and humoral immune responses. Br J Nutr, 98 Suppl 1:S29-35.

Maes M. (2008). The cytokine hypothesis of depression: inflammation, oxidative \& nitrosative stress (IO\&NS) and leaky gut as new targets for adjunctive treatments in depression. Neuroendocrinol Lett, 29(3):287-91.

Marar O, Senturk S, Agha A, Thompson C, Smith D. (2011). The prevalence of vitamin B12 deficiency in patients with type 2 diabetes mellitus on metformin. RCSI Student Medical Journal 4(1):16-20.

McGrath LT, Douglas AF, McClean E, Brown JH, Doherty CC, Johnston GD, Archbold GP. (1995). Oxidative stress and erythrocyte membrane fluidity in patients undergoing regular dialysis. Clin Chim Acta, 235(2):179-188.

Meijers BK, De Preter V, Verbeke K, Vanrenterghem Y, Evenepoel P. (2010). p-Cresyl sulfate serum concentrations in haemodialysis patients are reduced by the prebiotic oligofructose-enriched inulin. Nephrol Dial Transplant, 25(1):219-224.

Mendoza PD, Fenves AZ, Punar M, Stone MJ. (2010). Subcutaneous beta2-microglobulin amyloid shoulder nodulesin a long-term hemodialysis patient. Proc (Bayl Univ Med Cent), 23(2):139-141.

Metz TO, Alderson NL, Thorpe SR, Baynes JW. (2003). Pyridoxamine, an inhibitor of advanced glycation and lipoxidation reactions: a novel therapy for treatment of diabetic complications. Arch Biochem Biophys, 419(1):41-49.

Montazerifar F, Hashemi M, Karajibani M, Dikshit M. (2010). Hemodialysis alters lipid profiles, total antioxidant capacity, and vitamins $\mathrm{A}, \mathrm{E}$, and $\mathrm{C}$ concentrations in humans. J Med Food, 13(6):1490- 1493.

Morena M, Delbosc S, Dupuy AM, Canaud B, Cristol JP. (2005). Overproduction of reactive oxygen species in end-stage renal disease patients: a potential component of hemodialysis-associated inflammation. Hemodial Int, 9(1):37-46. 
Morimoto H, Nakao K, Fukuoka K, Sarai A, Yano A, Kihara T, Fukuda S, Wada J, Makino H. (2005). Long-term use of vitamin E-coated polysulfone membrane reduces oxidative stress markers in haemodialysis patients. Nephrol Dial Transplant, 20(12):2775-82.

Morishita Y, Hanawa S, Miki T, Sugase T, Sugaya Y, Chinda J, Iimura O, Tsunematsu S, Ishibashi K, Kusano E. (2011). The association of plasma prorenin level with an oxidative stress marker, $8-\mathrm{OHdG}$, in nondiabetic hemodialysis patients. Clin Exp Nephrol, [Epub ahead of print]

Mune M, Yukawa S, Kishino M, Otani H, Kimura K, Nishikawa O, Takahashi T, Kodama N, Saika Y, Yamada Y. (1999). Effect of vitamin E on lipid metabolism and atherosclerosis in ESRD patients. Kidney Int Suppl, 71:S126-129.

Mydlík M, Derzsiová K, Rácz O, Sipulová A, Lovásová E, Petrovicová J. (2001). A modified dialyzer with vitamin $\mathrm{E}$ and antioxidant defense parameters. Kidney Int Suppl, 78:S144-147.

Mydlik M, Derzsiová K. (2008). Vitamins and quality of life in hemodialysis patients. J Nephrol, 21 ( Suppl 13):S129-133.

Mydlík M, Derzsiová K. (2010). Vitamin B6 and oxalic acid in clinical nephrology. J Ren Nutr, 20(5 Suppl): S95-102.

Mydlík M, Derzsiová K, Zemberová E. (1997). Metabolism of vitamin B6 and its requirement in chronic renal failure. Kidney Int Suppl, 62:S56-59.

Nahas R. (2008). Complementary and alternative medicine approaches to blood pressure reduction: An evidence-based review. Can Fam Physician, 54(11):1529-1533.

Nakamura N, Fujita T, Kumasaka R, Murakami R, Shimada M, Shimaya Y, Osawa H, Yamabe H, Okumura K. (2008). Serum lipid profile and plasma fatty acid composition in hemodialysis patients- comparison with chronic kidney disease patients. In Vivo, 22(5):609-611.

Navarro-Alarcon M, Reyers-Perez A, LopezGarcia H, Palomares-Bayo M, Olalla-Herrera M, Lopez-Martinez MC. (2006). Longitudinal study of serum zinc and copper levels in hemodialysis patients and their relation to biochemical markers. Biol Trace Elem Res, 113(3):209-222.

Neve J. (1996). Selenium as a risk factor for cardiovascular diseases. J Cardiovasc Risk, 3(1):4247.

Ngom PT, Howie, S, Ota MO, Prentice AM. (2011). The potential role and possible immunological mechanisms of zinc adjunctive therapy for severe pneumonia in children. The Open Immunology Journal, 4: 1-10.

Nihi MM, Manfro RC, Martins C, Suliman M, Murayama Y, Riella MC, Lindholm B, Nascimento MM. (2010). Association between body fat, inflammation and oxidative stress in hemodialysis. J Bras Nefrol, 32(1):9-15.

Nishiyama S, Kiwaki K, Miyazaki Y, Hasuda T. (1999). Zinc and IGF-I concentrations in pregnant women with anemia before and after supplementation with iron and/or zinc. J Am Coll Nutr, 18(3):261-267.

Niwa T. (2010). Indoxyl sulfate is a nephro-vascular toxin. J Ren Nutr, 20(5 Suppl):S2-6.

Niwa T. (2011). Update of uremic toxin research by mass spectrometry. Mass Spectrom Rev, 30(3): 510- 521. 
Obeid R, Herrmann W. (2006). Mechanisms of homocysteine neurotoxicity in neurodegenerative diseases with special reference to dementia. FEBS Lett, 580(13):2994-3005.

O'Dell BL. (2000). Role of zinc in plasma membrane function. J Nutr, 130(5S Suppl):1432S$1436 \mathrm{~S}$.

Okada H, Moriwaki K, Kanno Y, Sugahara S, Nakamoto H, Yoshizawa M, Suzuki H. (2000). Vitamin B6 supplementation can improve peripheral polyneuropathy in patients with chronic renal failure on high-flux haemodialysis and human recombinant erythropoietin. Nephrol Dial Transplant. 15(9): 1410-1413.

Okamoto H, Kawaguchi H, Togashi H, Minami M, Saito H, Yasuda H. (1991). Effect of coenzyme Q10 on structural alterations in the renal membrane of stroke-prone spontaneously hypertensive rats. Biochem Med Metab Biol, 45(2):216-226.

Overvad K, Wang DY, Olsen J, Allen DS, Thorling EB, Bulbrook RD, Hayward JI. (1993). Copper in human mammary carcinogenesis: a case-cohort study. Ann J Epidemiol, 137(4):409-414

Pakfetrat M, Malekmakan L, Hasheminasab M. (2010). Diminished selenium levels in hemodialysis and continuous ambulatory peritoneal dialysis patients. Biol Trace Elem Res, 137(3):335-339.

Panichi V, Taccola D, Rizza GM, Consani C, Migliori M, Filippi C, Paoletti S, Sidoti A, Borracelli D, Panicucci E, Giovannini L. (2004). Ceruloplasmin and acute phase protein levels are associated with cardiovascular disease in chronic dialysis patients. J Nephrol, 17(5): 715-720.

Panicker S, Swathy SS, John F, Madambath I. (2010). Impact of selenium on NFkB translocation in isoproterenol-induced myocardial infarction in rats. Biol Trace Elem Res, 138(1-3):202-211.

Paoli P, Sbrana F, Tiribilli B, Caselli A, Pantera B, Cirri P, De Donatis A, Formigli L, Nosi D, Manao G, Camici G, Ramponi G. (2010). Protein N-homocysteinylation induces the formation of toxic amyloid-like protofibrils. J Mol Biol, 400(4):889-907.

Pastore A, De Angelis S, Casciani S, Ruggia R, Di Giovamberardino G, Noce A, Splendiani G, Cortese C, Federici G, Dessi' M. (2006). Effects of folic acid before and after vitamin B12 on plasma homocysteine concentrations in hemodialysis patients with known MTHFR genotypes. Clin Chem, 52(1):145-148.

Peake JM, Gobe GC, Fassett RG, Coombes JS. (2011). The effects of dietary fish oil on inflammation, fibrosis and oxidative stress associated with obstructive renal injury in rats. Mol Nutr Food Res. 55(3):400-410.

Peck L, Monsen E, Ahmad S. (1996). Effect of three sources of long-chain fatty acids on the plasma fatty acid profile, plasma prostaglandin E2 concentrations and pruritus symptoms in hemodialysis patients. Am J Clin Nutr. 64(2):210-214.

Pekmezci D. (2011). Vitamin E and immunity. Vitam Horm, 86:179-215.

Perunicic-Pekovic GB, Rasic ZR, Pljesa SI, Sobajic SS, Djuricic I, Maletic R, Ristic-Medic DK. (2007). Effect of n-3 fatty acids on nutritional status and inflammatory markers in haemodialysis patients. Nephrology (Carlton). 12(4):331-336. 
Playford DA, Watts GF, Croft KD, Burke V. (2003). Combined effect of coenzyme Q10 and fenofibrate on forearm microcirculatory function in type 2 diabetes. Atherosclerosis, 168(1):169-179.

Pooya Sh, Jalali MD, Jazayery AD, Saedisomeolia A, Eshraghian MR, Toorang F. (2010). The efficacy of omega-3 fatty acid supplementation on plasma homocysteine and malondialdehyde levels of type 2 diabetic patients. Nutr Metab Cardiovasc Dis, 20(5):326-331.

Poulia KA, Panagiotakos DB, Tourlede E, Rezou A, Stamatiadis D, Boletis J, Zampelas A. (2011). Omega-3 Fatty acids supplementation does not affect serum lipids in chronic hemodialysis patients. J Ren Nutr, [Epub ahead of print]

Raimundo P, Ravasco P, Proença V, Camilo M. (2006). Does nutrition play a role in the quality of life of patients under chronic haemodialysis? Nutr Hosp. 21(2):139-144.

Ramos R, Gómez-Geriqué N, Martínez-Castelao A. (2005). Lipoprotein oxidation profile in end stage renal disease patients. Role of vitamin C supplementation. Nefrologia, 25(2):178-184.

Rashidi AA, Salehi M, Piroozmand A, Sagheb MM. (2009). Effects of zinc supplementation on serum zinc and C-reactive protein concentrations in hemodialysis patients. J Ren Nutr, 19(6):475-478.

Rasic-Milutinovic Z, Perunicic G, Pljesa S, Gluvic Z, Sobajic S, Djuric I, Ristic D. (2007). Effects of N-3 PUFAs supplementation on insulin resistance and inflammatory biomarkers in hemodialysis patients. Ren Fail, 29(3):321-329.

Rasmussen LE, Svensson M, Jørgensen KA, Schmidt EB, Christensen JH. (2010). The content of docosahexaenoic acid in serum phospholipid is inversely correlated with plasma homocysteine levels in patients with end-stage renal disease. Nutr Res, 30(8):535540 .

Rayman MP. (2000). The importance of selenium to human health. Lancet, 356(9225): 233241.

Rayman MP, Stranges S, Griffin BA, Pastor-Barriuso R, Guallar E. (2011). Effect of supplementation with high- selenium yeast on plasma lipids: a randomized trial. Ann Intern Med, 154(10):656-665.

Reed A, Cho YJ, Coombes JS, Fassett RG. (2009). Time course and dose response of alpha tocopherol on oxidative stress in haemodialysis patients. BMC Nephrol, 10:32.

Richter A, Kuhlmann MK, Seibert E, Kotanko P, Levin NW, Handelman GJ. (2008). Vitamin $\mathrm{C}$ deficiency and secondary hyperparathyroidism in chronic haemodialysis patients. Nephrol Dial Transplant, 23(6):2058-2063.

Roozbeh J, Hedayati P, Sagheb MM, Sharifian M, Hamidian Jahromi A, Shaabani S, Jalaeian H, Raeisjalali GA, Behzadi S. (2009). Effect of zinc supplementation on triglyceride, cholesterol, LDL, and HDL levels in zinc-deficient hemodialysis patients. Ren Fail, 31(9):798-801.

Roozbeh J, Sharifian M, Ghanizadeh A, Sahraian A, Sagheb MM, Shabani S, Hamidian Jahromi A, Kashfi M, Afshariani R. (2011). Association of zinc deficiency and depression in the patients with end-stage renal disease on hemodialysis. J Ren Nutr, 21(2):184-187. 
Rosenfeldt FL, Haas SJ, Krum H, Hadj A, Ng K, Leong JY, Watts GF. (2007). Coenzyme Q10 in the treatment of hypertension: a meta-analysis of the clinical trials. J Hum Hypertens, 21(4):297-306.

Ryo K, Ito A, Takatori R, Tai Y, Arikawa K, Seido T, Yamada T, Shinpo K, Tamaki Y, Fujii K, Yamamoto Y, Saito I. (2011). Effects of coenzyme Q10 on salivary secretion. Clin Biochem, 44(8-9):669-674.

Saifullah A, Watkins BA, Saha C, Li Y, Moe SM, Friedman AN. (2007). Oral fish oil supplementation raises blood omega-3 levels and lowers C-reactive protein in haemodialysis patients--a pilot study. Nephrol Dial Transplant, 22(12):3561-3567.

Saint-Georges MD, Bonnefont DJ, Bourely BA, Jaudon MC, Cereze P, Chaumeil P, Gard C, D'Auzac CL. (1989). Correction of selenium deficiency in hemodialyzed patients. Kidney Int Suppl, 27:S274-S277.

Sakata T, Furuya R, Shimazu T, Odamaki M, Ohkawa S, Kumagai H. (2008). Coenzyme Q10 administration suppresses both oxidative and antioxidative markers in hemodialysis patients. Blood Purif, 26(4):371-378.

Schmelzer C, Kubo H, Mori M, Sawashita J, Kitano M, Hosoe K, Boomgaarden I, Döring F, Higuchi K. (2010). Supplementation with the reduced form of Coenzyme Q10 decelerates phenotypic characteristics of senescence and induces a peroxisome proliferator-activated receptor-alpha gene expression signature in SAMP1 mice. Mol Nutr Food Res, 54(6):805-815.

Shi XF, Ding F, Zhu QY, Xue J, Lu FM, Gu Y, Lin ST. Use of ascorbate-rich dialysate to attenuate oxidative stress in maintenance hemodialysis patients. Ren Fail, 27(2):213219.

Shojaei M, Djalali M, Khatami M, Siassi F, Eshraghian M. (2011). Effects of carnitine and coenzyme Q10 on lipid profile and serum levels of lipoprotein(a) in maintenance hemodialysis patients on statin therapy. Iran J Kidney Dis, 5(2):114-118.

Siener R, Jansen B, Watzer B, Hesse A. (2011). Effect of n-3 fatty acid supplementation on urinary risk factors for calcium oxalate stone formation. J Urol, 185(2):719-724.

Singh RB, Niaz MA. (1999). Serum concentration of lipoprotein(a) decreases on treatment with hydrosoluble coenzyme Q10 in patients with coronary artery disease: discovery of a new role. Int J Cardiol, 68(1):23-29.

Singhi SC, Baranwal A. (2008). Probiotic use in the critically ill. Indian J Pediatr, 75(6):621-627.

Sirover WD, Siddiqui AA, Benz RL. (2008). Beneficial hematologic effects of daily oral ascorbic acid therapy in ESRD patients with anemia and abnormal iron homeostasis: a preliminary study. Ren Fail, 30(9):884-889.

Sombolos K, Fragia T, Natse T, Bartholomatos G, Karagianni A, Katsaris G, Christidou F, Bamichas G, Stangou M, Papagalanis N. (2002). The effect of long-term intravenous high dose B-complex vitamins with or without folic acid on serum homocysteine in hemodialysis patients. J Nephrol, 15(6):671-655.

Soumura M, Kume S, Isshiki K, Takeda N, Araki S, Tanaka Y, Sugimoto T, Chin-Kanasaki M, Nishio Y, Haneda M, Koya D, Kashiwagi A, Maegawa H, Uzu T. (2010). Oleate and eicosapentaenoic acid attenuate palmitate-induced inflammation and apoptosis in renal proximal tubular cell. Biochem Biophys Res Commun, 402(2):265-271. 
Srikanth R, Mendoza VL, Bridgewater JD, Zhang G, Vachet RW. (2009). Copper binding to beta-2- microglobulin and its pre-amyloid oligomers. Biochemistry, 48(41):9871-9881.

Stanford JL, Molina H, Phillips J, Kohlman-Trigoboff D, Moore J, Smith BM. (2000). Oral folate reduces plasma homocyst(e)ine levels in hemodialysis patients with cardiovascular disease. Cardiovasc Surg, 8(7):567-571.

Stenvinkel P. (2003). Anaemia and inflammation: what are the implications for the nephrologist? Nephrol Dial Transplant, 18( Suppl 8):viii17-22.

Stopper H, Treutlein AT, Bahner U, Schupp N, Schmid U, Brink A, Perna A, Heidland A. (2008). Reduction of the genomic damage level in haemodialysis patients by folic acid and vitamin B12 supplementation. Nephrol Dial Transplant, 23(10):3272-3279.

Strid H, Simren M, Johansson AC, Svedlund J, Samuelsson O, Bjornsson ES. (2002). The prevalence of gastrointestinal symptoms in patients with chronic renal failure is increased and associated with impaired psychological general wellbeing. Nephrol Dial Transplant, 17(8):1434-1439.

Svensson M, Christensen JH, Sølling J, Schmidt EB. (2004). The effect of n-3 fatty acids on plasma lipids and lipoproteins and blood pressure in patients with CRF. Am J Kidney Dis, 44(1):77-83.

Taccone-Gallucci M, Manca-di-Villahermosa S, Battistini L, Stuffler RG, Tedesco M, Maccarrone M. (2006). N-3 PUFAs reduce oxidative stress in ESRD patients on maintenance HD by inhibiting 5-lipoxygenase activity. Kidney Int, 69(8):1450-1454.

Taccone-Gallucci M, Noce A, Bertucci P, Fabbri C, Manca-di-Villahermosa S, Della-Rovere FR, De Francesco M, Lonzi M, Federici G, Scaccia F, Dessì M. (2010). Chronic treatment with statins increases the availability of selenium in the antioxidant defence systems of hemodialysis patients. J Trace Elems Med Biol, 24(1):27-30.

Taki K, Takayama F, Tsuruta Y, Niwa T. (2006). Oxidative stress, advanced glycation end product, and coronary artery calcification in hemodialysis patients. Kidney Int, $70(1): 218-224$.

Tamura T, Johnston KE, Bergman SM. (1996). Homocysteine and folate concentrations in blood from patients treated with hemodialysis. J Am Soc Nephrol, 7(11):2414-2418.

Tarng DC, Liu TY, Huang TP. (2004). Protective effect of vitamin C on 8-hydroxy-2'deoxyguanosine level in peripheral blood lymphocytes of chronic hemodialysis patients. Kidney Int, 66(2):820-831.

Taziki O, Lessan-Pezeshki M, Akha O, Vasheghani F. (2007). The effect of low dose omega-3 on plasma lipids in hemodialysis patients. Saudi J Kidney Dis Transpl, 18(4):571-576.

Thamilselvan S, Menon M. (2005). Vitamin E therapy prevents hyperoxaluria-induced calcium oxalate crystal deposition in the kidney by improving renal tissue antioxidant status. BJU Int, 96(1):117-126.

Thomas SR, Stocker R. (2001). Mechanisms of antioxidant action of ubiquinol-10 for lowdensity lipoprotein. In: Kagan VE, Quinn PJ, eds. Coenzyme Q: Molecular Mechanisms in Health and Disease. Boca Raton: CRC Press, 131-150.

Tonelli M, Wiebe N, Hemmelgarn B, Klarenbach S, Field C, Manns B, Thadhani R, Gill J. (2009). Trace elements in hemodialysis patients: a systematic review and metaanalysis. BMC Med, 7:25. 
Tremblay R, Bonnardeaux A, Geadah D, Busque L, Lebrun M, Ouimet D, Leblanc M. (2000). Hyperhomocysteinemia in hemodialysis patients: effects of 12-month supplementation with hydrosoluble vitamins. Kidney Int, 58(2):851-888.

Veighey K, Booth J, Davenport A. (2011). Does the choice of phosphate binder affect trace element levels in chronic kidney disease patients treated by regular haemodialysis? Nephrol Dial Transplant, 26(3): 1006-1010.

Viron B. (2002). The point about...uremia and cancer. Nephrologie, 23(6):231-236.

Wada S. (2011). Cancer Preventive Effects of Vitamin E. Curr Pharm Biotechnol, [Epub ahead of print]

Walston J, Xue Q, Semba RD, Ferrucci L, Cappola AR, Ricks M, Guralnik J, Fried LP. (2006). Serum antioxidants, inflammation, and total mortality in older women. Am J Epidemiol, 163: 18-26.

Wannamethee SG, Lowe GD, Rumley A, Bruckdorfer KR, Whincup PH. (2006). Associations of vitamin $C$ status, fruit and vegetable intakes, and markers of inflammation and hemostasis. Am J Clin Nutr, 83(3):567-74; quiz 726-727.

Ward RA, McLeish KR. (2003). Oxidant stress in hemodialysis patients: what are the determining factors? Artif Organs, 27(3):230-236.

Washio K, Inagaki M, Tsuji M, Morio Y, Akiyama S, Gotoh H, Gotoh T, Gotoh Y, Oguchi K. (2008). Oral vitamin C supplementation in hemodialysis patients and its effect on the plasma level of oxidized ascorbic acid and $\mathrm{Cu} / \mathrm{Zn}$ superoxide dismutase, an oxidative stress marker. Nephron Clin Pract, 109(2):c49-c54.

Watts GF, Playford DA, Croft KD, Ward NC, Mori TA, Burke V. (2002). Coenzyme Q(10) improves endothelial dysfunction of the brachial artery in Type II diabetes mellitus. Diabetologia, 45(3):420-426.

Weissinger EM, Nguyen-Khoa T, Fumeron C, Saltiel C, Walden M, Kaiser T, Mischak H, Drüeke TB, Lacour B, Massy ZA. (2006). Effects of oral vitamin C supplementation in hemodialysis patients: a proteomic assessment. Proteomics, 6(3):993-1000.

Whitin JC, Tham DM, Bhamre S, Ornt DB, Scandling JD, Tune BM, Salvatierra O, Avissar N, Cohen HJ. (1998). Plasma glutathione peroxidase and its relationship to renal proximal tubule function. Mol Genet Metab, 65(3):238-245.

Yamauchi M, Yamaguchi T, Nawata K, Takaoka S, Sugimoto T. (2010). Relationships between undercarboxylated osteocalcin and vitamin $\mathrm{K}$ intakes, bone turnover, and bone mineral density in healthy women. Clin Nutr, 29(6):761-765.

Yukawa S, Mune M, Otani H. (1999). Vitamin E disturbances in chronic renal failure. Nippon Rinsho, 57(10):2366-2370.

Zachara BA, Adamowicz A, Trafikowska U, Trafikowska A, Manitius J, Nartowicz E. (2001). Selenium and glutathione levels, and glutathione peroxidase activities in blood components of uremic patients on hemodialysis supplemented with selenium and treated with erythropoietin. J Trace Elem Med Biol, 15(4):201-208.

Zachara BA, Gromadzinska J, Palus J, Zbrog Z, Swiech R, Twardowska E, Wasowicz W. (2010). The effect of selenium supplementation in the prevention of DNA damage in white blood cells of hemodialyzed patients: A pilot study. Biol Trace Elem Res, [Epub ahead of print] 
Zachara BA, Gromadzinska J, Zbrog Z, Swiech R, Wasowicz W, Twardowska E, Jablonska E, Sobala W. (2009). Selenium supplementation to chronic kidney disease patients on hemodialysis does not induce the synthesis of plasma glutathione peroxidase. Acta Biochim Pol, 56(1):183-187.

Zagrodzki P, Bartoń H, Walas S, Fołta M, Stompór T, Janusz-Grzybowska E, Drozdz M, Sułowicz W. (2007). Selenium status indices, laboratory data, and selected biochemical parameters in end-stage renal disease patients. Biol Trace Elem Res, 116(1):29-41.

Ziakka S, Rammos G, Kountouris S, Doulgerakis C, Karakasis P, Kourvelou C, Papagalanis N. (2001). The effect of vitamin B6 and folate supplements on plasma homocysteine and serum lipids levels in patients on regular hemodialysis. Int Urol Nephrol, 33(3):559-562.

Zwolinska D, Grzeszcza kW, Szczepanska M, Makulska I, Kilis-Pstrusinska K, Szprynger K. (2009). Oxidative stress in children on peritoneal dialysis. Perit Dial Int, 29(2):171177. 


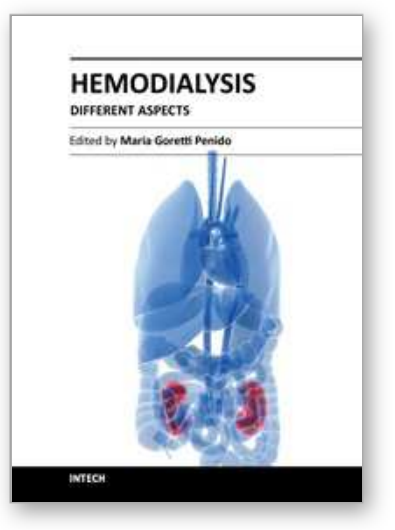

\author{
Hemodialysis - Different Aspects \\ Edited by Prof. Maria Goretti Penido
}

ISBN 978-953-307-315-6

Hard cover, 321 pages

Publisher InTech

Published online 14, November, 2011

Published in print edition November, 2011

The book provides practical and accessible information on all aspects of hemodialysis, with emphasis on dayto-day management of patients. It is quite comprehensive as it covers almost all the aspects of hemodialysis. In short it is a valuable book and an essential aid in the dialysis room.

\title{
How to reference
}

In order to correctly reference this scholarly work, feel free to copy and paste the following:

Chih-Hung Guo, Chia-Liang Wang and Pei-Chung Chen (2011). Micronutrient Metabolism in Hemodialysis Patients, Hemodialysis - Different Aspects, Prof. Maria Goretti Penido (Ed.), ISBN: 978-953-307-315-6, InTech, Available from: http://www.intechopen.com/books/hemodialysis-different-aspects/micronutrient-metabolism-inhemodialysis-patients

\section{INTECH}

open science | open minds

\section{InTech Europe}

University Campus STeP Ri

Slavka Krautzeka 83/A

51000 Rijeka, Croatia

Phone: +385 (51) 770447

Fax: +385 (51) 686166

www.intechopen.com

\section{InTech China}

Unit 405, Office Block, Hotel Equatorial Shanghai

No.65, Yan An Road (West), Shanghai, 200040, China

中国上海市延安西路65号上海国际贵都大饭店办公楼405单元

Phone: +86-21-62489820

Fax: $+86-21-62489821$ 
(C) 2011 The Author(s). Licensee IntechOpen. This is an open access article distributed under the terms of the Creative Commons Attribution 3.0 License, which permits unrestricted use, distribution, and reproduction in any medium, provided the original work is properly cited. 